\title{
Effect of food availability on offspring sex ratios in replacement clutches of Mew Gulls (Larus canus) and Black-headed Gulls (Chroicocephalus ridibundus) in the highly unstable environment of the Vistula River
}

\author{
Dariusz Bukaciński ${ }^{1}$ (i) $\cdot$ Monika Bukacińska ${ }^{1}$ Przemysław Chylarecki
}

Received: 1 June 2019 / Revised: 7 February 2020 / Accepted: 27 February 2020 / Published online: 19 March 2020

(c) The Author(s) 2020

\begin{abstract}
The reproductive cost hypothesis predicts that parents with low investment capacity (e.g., those in poor condition) should produce the larger sex (usually males) less often so as to minimize the risk of current reproductive failure and/or a decrease in their residual reproductive value. The study aimed to test whether offspring sex ratio bias in replacement clutches of the Mew Gull (MG; Larus canus) and Black-headed Gull (BHG; Chroicocephalus ridibundus) exposed to different food conditions was in agreement with predictions of the reproductive cost hypothesis. Food availability was experimentally modified before egg laying. Our experimental treatment affected hatching sex ratio, being also significant the effect of laying order and species identity. For both gull species, parents that were provided with supplemental food had more sons at hatching than unfed (control) pairs. This was particularly so if they were fed until production of a replacement clutch. This gradient in hatching sex ratio was much more pronounced in MG than in BHG. In both gull species, sons hatched more often from first laid (A) than from second (B) or third-laid egg (C). Five days after hatching, the sex ratio of surviving chicks was dependent mainly on the experimental treatment and egg sequence. Unlike the time of hatching, there was no important effect of species $\times$ treatment interaction. In both gull species, the brood sex-ratio was clearly male-biased in parents receiving supplemental feeding. However, differences between experimental groups were less extreme than at hatching. Chicks hatched from C-egg had much lower survival than chicks from the first two eggs (A- and B-egg), irrespective of sex, treatment, or species. Supplementary feeding was associated with improved chick survival for both gull species, although this effect was dependent on chick gender. Surprisingly, in the case of control broods (i.e., broods whose parents did not receive supplementary food), male chicks survived better than female chicks, but the opposite was true for broods in which parents were fed. There was an overall tendency for higher survival of BHG chicks than MG chicks. During the early-chick period, competition between siblings and the related differentiated mortality of chicks from A-, B-, and C-eggs, constituted a mechanism which shaped the brood sex ratio bias. In this context, differences in the sex ratio bias in eggs of different rank $(\mathrm{A}, \mathrm{B}, \mathrm{C})$ at hatching were important. The results appear to fulfil the expectations of the reproductive cost hypothesis. For the species with greater sexual dimorphism (MG), a relationship between the condition of parents and the expected bias of sex ratio was visible only at hatching, which may indicate that this feature is not significant in shaping the sex ratio bias in MG.
\end{abstract}

Keywords Black-headed gull $\cdot$ Food availability $\cdot$ Mew gull $\cdot$ Offspring sex ratios $\cdot$ Replacement clutches $\cdot$ Sexual size dimorphism

Communicated by C. Barbraud.

Dariusz Bukaciński

dbukacinski@op.pl

Extended author information available on the last page of the article 


\section{Zusammenfassung}

Auswirkung des Futterangebotes auf das Geschlechterverhältnis bei Jungen in Nachgelegen von Sturmmöwen (Larus canus) und Lachmöwen (Chroicocephalus ridibundus) in einem hochgradig instabilen Ökosystem an der Weichsel

Die Reproduktionskosten-Hypothese besagt, dass Elterntiere mit geringen Investitionsmöglichkeiten (z.B. wegen eines schlechten Gesamtzustands) weniger häufig Nachkommen des größeren Geschlechts (normalerweise Männchen) zeugen, um das Risiko eines Fortpflanzungsausfalls oder einer Verringerung ihres Rest-Fortpflanzungswertes so gering wie möglich zu halten. Unsere Untersuchung sollte feststellen, ob das Geschlechterverhältnis der Jungen in Nachgelegen von Sturmmöwen (Larus canus) und Lachmöwen (Chroicocephalus ridibundus), die unterschiedliche Futterangebote erhielten, mit den Vorhersagen der Reproduktionskosten-Hypothese in Übereinklang stand. Das Futterangebot wurde vor der Eiablage verändert. Unsere Versuche beeinflussten in der Tat das Geschlechterverhältnis der Geschlüpften sowie in signifikanter Weise auch die Reihenfolge der Eiablage. Bei beiden Möwenarten hatten diejenigen Eltern, die zusätzliches Futter erhielten, mehr geschlüpfte Söhne als die nicht zusätzlich gefütterten (Kontroll-)Paare. Dies galt vor allem, wenn sie bis zur Ablage eines Nachgeleges gefüttert wurden. Der Gradient im Geschlechterverhältnis der frisch Geschlüpften war bei den Sturmmöwen stärker ausgeprägt als bei den Lachmöwen. Bei beiden Möwenarten gab es bei den erstgelegten Eiern (A) mehr Söhne als bei den zweit- (B) oder drittgelegten (C). Fünf Tage nach dem Schlüpfen hing das Geschlechterverhältnis der überlebenden Küken in erster Linie von der experimentellen Behandlung und von der Reihenfolge der gelegten Eier ab. Abgesehen vom Zeitpunkt des Schlüpfens konnten keine wichtigen Effekte im Zusammenhang zwischen Möwenart und experimenteller Behandlung festgestellt werden. Bei beiden Möwenarten gab es ein klares Übergewicht an männlichen Jungen bei den Eltern mit zusätzlichem Futter. Aber die Unterschiede zwischen allen Gruppen des Experiments waren weniger groß als beim Schlüpfen. Küken aus C-Eiern zeigten unabhängig von Geschlecht, Behandlung oder Spezies eine viel kleinere Überlebensrate als solche aus den ersten zwei gelegten Eiern (A und B). Bei beiden Möwenarten war die zusätzliche Fütterung mit einer höheren Überlebensrate verbunden, wobei dieser Effekt jedoch vom Geschlecht der Küken abhing. Überraschenderweise überlebten in den Kontrollbruten (deren Eltern kein zusätzliches Futter erhielten) mehr männliche als weibliche Küken, aber in den Gruppen mit zusätzlichem Futter war es umgekehrt. Die Küken der Lachmöwen zeigten tendenziell eine höhere Überlebensrate als die der Sturmmöwen. Während der ersten Zeit nach dem Schlüpfen bildete die Konkurrenz zwischen den Geschwistern und die unterschiedliche Sterberate der Küken aus A-, B- und C-Eiern eine Art Mechanismus, aus dem sich das Geschlechterverhältnis in den Bruten ergab. In diesem Zusammenhang gewannen die Unterschiede in den Geschlechterverhältnissen der Jungen aus A-, B- und C-Eiern an Bedeutung. Diese Ergebnisse scheinen die Erwartungen aus der Reproduktionskosten-Hypothese zu erfüllen. Für die Art mit dem größeren Geschlechtsdimorphismus (Sturmmöwen) gab es nur beim Schlüpfen einen Zusammenhang zwischen der Gesamtverfassung der Eltern und dem zu erwartenden Geschlechterverhältnis, was nahelegt, dass dieses Merkmal bei Sturmmöwen nicht wichtig für das Zustandekommen des Geschlechterverhältnisses ist.

\section{Introduction}

Sex allocation theory predicts that parents should adjust the sex ratio of their offspring according to the costs and benefits related to the production of one or the other sex in a given context (Charnov 1982; Frank 1990; West 2009). Several hypotheses have been proposed that focus on the different selection pressures that could potentially influence sex ratio adjustment in birds and mammals (reviewed in Cockburn et al. 2002). Although an adaptive sex ratio bias among offspring has been shown in a large number of studies (as reviewed in Alonso-Alvarez 2006; Komdeur 2012), the results are often inconsistent, even within the same species (Rosivall et al. 2004; Maddox and Weatherhead 2009; Merkling et al. 2015 vs. 2019). Other studies reported only a small sex ratio bias (Torres and Drummond 1999; Weimerskirch and Lys 2000; Boulet et al. 2001), lack of sex ratio bias, or even bias in the opposite direction than that predicted by models (Leech et al. 2001; Cockburn and Double 2008;
Oddie and Reim 2002; Kalmbach et al. 2005). This may reflect the fact that factors shaping the sex ratio are much more complex than those acknowledged in the most widely used sex allocation models.

Two of the most popular models of sex allocation-the reproductive cost hypothesis (Myers 1978; Cockburn et al. 2002) and the Trivers-Willard hypothesis (Trivers and Willard 1973) - focus on parental condition as a driver of observed variation in offspring sex ratio. They both predict that in species, where males are larger, females in poor condition should overproduce daughters, although such hypotheses differ regarding the postulated mechanisms (fitness return pathways, sensu Merkling et al. 2015) leading to such a bias. In birds with male-biased sexual size dimorphism, raising male offspring requires more parental investment. Parents in poor condition should be reluctant to invest in the sex that imposes greater demands on resources, due to the risk of reproductive failure in a given episode or impaired reproductive output in the future (i.e., the cost 
of reproduction). This would lead to selection of a femalebiased sex ratio in the broods of parents in poor condition (Myers 1978). In addition, if variation in parental investment carries over into adulthood and provides fitness benefits for better-nourished males (e.g., during inter-male competition), parents in good condition should produce sons rather than daughters (Trivers and Willard 1973). However, many other factors may significantly influence the brood sex ratio, altering the proportions predicted by theoretical models of adaptive sex allocation. These include environmental factors, age effects, inter-brood competition, timing of breeding, mate quality, etc. (Carranza and Polo 2012; Komdeur 2012; Booksmythe et al. 2017).

The factors shaping adaptive sex ratio allocation require further study, given the conflicting results reported in the literature. This is particularly so as it relates to the application of an experimental approach, as noted by Komdeur and Pen (2002) and Merkling et al. (2012). In this paper, we present the results of an experiment aimed at comparing patterns of brood sex ratio adjustment in the replacement clutches of the Mew Gull (Larus canus) and Black-headed Gull (Chroicocephalus ridibundus), which are two species that differ in their degree of sexual size dimorphism. We experimentally induced birds to lay replacement clutches while simultaneously providing them with different amounts of supplemental food (see "Methods") to increase their parental reproductive investment and to differentially improve their condition afterward (see, e.g., Heaney and Monaghan 1995; Nager et al. 1999; Kalmbach et al. 2005; Różycki 2014). In doing so, we mimicked the actual conditions experienced by gulls on our study site at the Vistula River in Poland (Bukaciński et al. 2020). Here, gulls breed on extensive islands and sandbars located within a braided river channel (Chmielewski and Tabor 2017) and suffer heavy losses each year. Frequent increases in the water level, but also mass outbreaks of black flies (Simuliidae) and heavy predation by American Minks (Neovison vison) and Red Foxes (Vulpes vulpes) mean that each year the majority of the breeding population experiences a clutch or brood loss (Bukaciński and Bukacińska 1994, 2000, 2003, 2015a, b). Gulls are longlived birds and laying replacement clutches repeatedly is costly (Nager et al. 2000b, 2001), which implies possible trade-offs between current and future reproduction (CluttonBrock 1991; Stearns 1992). This should result in a strong selective pressure to adjust reproductive investment of experimental female gulls to the level of their current individual reproductive capability (e.g., condition) if they decide to renest. Given consistently high, albeit spatially and temporally unpredictable, clutch loses, gulls of the Vistula river should not refrain from renesting if they are to produce any offspring in their lifetime. However, they should be selected to adaptively adjust clutch size and egg size in accordance with their current condition if reproductive costs can be carried over to the next breeding season, as demonstrated by Nager et al. (2001). We were able to demonstrate experimentally that reproductive output in our Mew Gull population is limited by food availability. Pairs that were given supplementary food laid larger clutches, larger eggs, and had enhanced breeding success (Różycki 2014; Wiśniewska 2014; Buczyński unpublished data). Importantly, adaptive sex allocation within the clutch offers some possibility of further adjustment of parental investment, as egg position in the laying sequence is linked to predictable differences in fledging success in gulls (Lundberg and Väisänen 1979; Bukacińska 1999; González-Solís et al. 2005; Kim and Monaghan 2006; Różycki 2014). The chances of survival to adulthood is usually considerably higher for chicks hatching from the first two eggs (A, B) compared to those from a last-laid egg (C). Consequently, the decision of sex allocation across successive eggs in a replacement clutch can be viewed as yet another level of fine-tuning of parental investment. Parents in poor condition should allocate more daughters into C-eggs than parents in good condition, as female chicks will be less susceptible to food shortage during the chick-rearing period.

We should expect that if reproduction in gulls adheres to a mechanism of adaptive sex allocation, the actual sex ratio found in (experimentally induced) replacement clutches should be adjusted in line with the condition of an experimentally manipulated female and the egg position in the laying sequence. Furthermore, we assumed that at least in Mew Gulls (a species with greater sexual size dimorphism), the production of sons is more expensive than daughters. One of the prerequisites was that sexual size dimorphism in this species occurs in the period of post-embryonic chick development, with males being larger and heavier than females close to fledging, although to a lesser extent (at 5-8\%) than in adult birds (Table 1, Bukaciński and Bukacińska, in prep.). Unlike other researchers (such as Merkling et al. 2015), we did not measure the actual energy and physiological costs associated with the production of offspring of different sexes. Sexual size dimorphism of chicks may be weakly correlated with the actual differences in the costs of raising sons and daughters (see for example, Torres and Drummond 1999; McDonald et al. 2005). The offspring sex ratio bias towards the 'cheaper' sex, which we found in pairs of naturally poorer condition (first clutches vs. replacement clutches, Bukaciński et al. 2020), corresponds well with this basic prediction of the reproductive cost hypothesis (Myers 1978; Cockburn et al. 2002). With this in mind, we expected that (a) parents in poorer condition will over-produce daughters (the presumed cheaper sex) and (b) this relationship will be more evident in a species with greater sexual size dimorphism (Mew Gull, Table 1). We knew from previous studies that food availability is one of the key factors affecting parental condition and reproductive success in our study 
Table 1 Sexual size-dimorphism (weight and structural dimensions) in adult Black-headed Gulls (Chroicocephalus ridibundus) and Mew Gulls (Larus canus)

Difference between male and female (as a \%)

\begin{tabular}{llll}
\hline Weight (\%) & $\begin{array}{l}\text { Wing } \\
\text { length }\end{array}$ & $\begin{array}{l}\text { Tarsus } \\
\text { length }\end{array}$ & $\begin{array}{l}\text { Head and } \\
\text { bill length } \\
(\%)\end{array}$ \\
& $(\%)$ & $(\%)$
\end{tabular}

Black-headed Gull

$\begin{array}{lllll}\begin{array}{c}\text { Literature data }^{\mathrm{a}} \\ \text { Mew Gull }\end{array} & 3-8 & 3-5 & 2-5 & 3-6 \\ \text { Literature data }^{\mathrm{a}} & 11-15 & 5-9 & 5-9 & 6-9 \\ \begin{array}{c}\text { Middle Vistula } \\ \text { River }{ }^{\mathrm{b}, \mathrm{c}}\end{array} & 12 & 7 & 7 & 8 \\ \end{array}$

${ }^{a}$ Glutz von Blotzheim and Bauer (1982), Cramp and Simmons (1985), Ilichev and Zubakin (1988)

${ }^{b}$ Bukaciński and Bukacińska, unpubl. data from the nest trapping in the years 1986-2016

${ }^{c}$ Bukaciński and Bukacińska (2003)

populations (see above). Considering the generally poor condition of parents during the time that replacement clutches were laid, we expected that supplemental feeding of some (i.e., fed1 and fed 2 pairs, see "Methods") will increase the variance of this trait, and thus increase the room for adaptive manipulation of offspring sex ratio that would be consistent with theoretical predictions of the reproduction cost hypothesis (Myers 1978; Cockburn et al. 2002).

We also wanted to test to what extent the sex ratio pattern found at the stage of egg-laying (primary sex ratio) will change during the first 5 days after hatching (early chick period), when the offspring mortality in the Vistula colonies of these species is at its highest (Bukaciński and Bukacińska 1995; Bukacińska 1999; Buczyński 2000; Pikulska 2017; Korzenecka 2019). We also examined the role of food availability to parents (our experimental treatment), the position of the egg in the laying sequence, and offspring sex, in relation to observed chick mortality patterns.

\section{Methods}

\section{Study area and species}

The study area included islands in the middle reaches of the Vistula River between Dęblin and the mouth of the Pilica River, Central Poland (km 393-457 of the waterway; 51 $31^{\circ}$ $\left.33.88^{\prime \prime}-51^{\circ} 51^{\prime} 45.19^{\prime \prime} \mathrm{N}, 21^{\circ} 49^{\prime} 35.86^{\prime \prime}-21^{\circ} 16^{\prime} 58.71^{\prime \prime} \mathrm{E}\right)$.

The study was conducted using colonies of Mew Gulls (MG) and Black-headed Gulls (BHG). These species feed on the same items during the breeding season, occupy similar breeding habitats, and nest at the same time (Ostrowska 1995; Bukaciński and Bukacińska 1994, 2003, 2015a, b).
Mew Gull males are 11-15\% heavier and 6-9\% larger than females, while BHG males are 3-8\% heavier and 3-5\% larger than females (Table 1). Sexual size dimorphism develops during the first weeks of life and prior to fledging (Bukaciński and Bukacińska in prep.), as is the case in many other size-dimorphic water birds (Becker and Wink 2003; Weimerskirch et al. 2000; Merkling et al. 2012). Every year, a few hundred MG pairs and a few thousand BHG pairs nest at the study location (Bukaciński et al. 2017).

\section{Field data collection}

We conducted our study between April and June of 2016. We marked all nests with numbered sticks, checked them every 2 days until clutch completion, and then every 3-5 days until hatching. We marked eggs in clutches as A, $\mathrm{B}$, and $\mathrm{C}$ according to their laying order with a non-toxic marker (hereafter referred to as A-egg, B-egg, and C-egg). We ringed the chicks just after hatching and recorded from which egg they hatched as well as the hatching order. We took approximately $40 \mu \mathrm{l}$ of blood from the tarsal vein of each chick and preserved it in $1 \mathrm{ml}$ of APS buffer (Arctander 1988) stored at $-20^{\circ} \mathrm{C}$ until DNA extraction and PCR analyses. We also collected biological material (liver or heart) from dead chicks in few cases, where they died just prior to planned blood extraction and preserved such material in $1 \mathrm{ml}$ of Queens Buffer (Seutin et al. 1991) until molecular analyses. Most adults were individually marked with coloured rings in earlier years. The remaining birds were trapped on their nests and ringed during the study year.

\section{Experimental treatment: a diversification of food availability at breeding sites}

On the Vistula River, the breeding season of gulls lasts longer (and the level of investment in egg production is higher) than in other, more stable environments occupied by BHGs and MGs (Glutz von Blotzheim and Bauer 1982; Cramp et al. 1985; Ilichev and Zubakin 1988; Bukaciński and Bukacińska 2003). When planning an experiment, we tried to imitate the natural environmental conditions of the middle Vistula River. Therefore, we used replacement clutches, which are the norm at this study site, rather than the exception (Table 2). Monaghan et al. (1998) found that an increase in production of one egg reduced body weight and protein reserves of Lesser Black-backed Gulls (Larus fuscus) by at least 5-6\%. Under the Vistula conditions, the weight of MG females incubating replacement clutches was $12-22 \%$ lower, depending on the year and individual, in comparison to that of the same birds laying their first clutches (Wiśniewska 2014; Bukaciński and Bukacińska unpublished data). To understand the importance of current food conditions and their effect on biases in offspring 
Table 2 Percentage of the Black-headed Gull (Chroicocephalus ridibundus) and Mew Gull (Larus canus) pairs who lost first clutches and re-nested (from losing pairs) on the middle Vistula River islands in the years 2000-2015

\begin{tabular}{|c|c|c|c|}
\hline & \multirow[t]{2}{*}{ Number of pairs } & \multicolumn{2}{|c|}{ Frequency of pairs (as a \%) } \\
\hline & & Losing first clutches & Renesting \\
\hline \multicolumn{4}{|c|}{ Black-headed Gull } \\
\hline Min-max & $151-454$ & $43.7-100.0$ & $22.0-77.0$ \\
\hline Mean \pm SD & $267 \pm 111$ & $57.1 \pm 15.7$ & $41.2 \pm 22.6$ \\
\hline \multicolumn{4}{|l|}{ Mew Gull } \\
\hline Min-max & $202-444$ & $70.2-100.0$ & $34.0-98.0$ \\
\hline Mean \pm SD & $334 \pm 94$ & $89.4 \pm 8.8$ & $67.0 \pm 23.2$ \\
\hline
\end{tabular}

The range (minimum-maximum) and means with standard deviation $($ mean \pm SD) are presented

sex ratios in replacement clutches, we induced females from groups of pairs with experimentally differentiated availability of high quality food to renest. For the analyses, we used breeding pairs that had begun laying no later than the peak of a given season (i.e., no later than April 25 for BHGs and May 10 for MGs), for which the first and replacement clutches consisted of three eggs.

Due to the fact that frequent increases in water levels, along with significant predation by American Minks and Red Foxes, cause the majority of MG pairs and a large proportion of BHG pairs to quickly lose their clutches (see Table 2), it was necessary to protect three-egg replacement clutches until the time of hatching. For this purpose, we used a method of active gull protection (Bukaciński and Bukacińska 2008; Bukaciński 2015; Bukaciński et al. 2018). Shortly after laying, each egg was taken from the nest to an incubator and a wooden dummy, painted to appear like the original egg, was put in its place. Just before hatching, we returned the clutches from the incubator to the nests from which they were taken. We did not observe any incidents of desertion or less intensive incubation in nests with dummy eggs (Bukaciński 2015; Bukaciński et al. 2018). This was the case both during this study and in earlier and subsequent projects involving active gull protection in Poland.

For both species, we randomly selected three groups consisting of breeding pairs. Two of them we started to feed 12-14 days before laying of the first egg within the breeding territories of particular pairs. After completion of egg-laying, the first clutches from all three groups were removed. That is, the clutches were taken to an incubator and transferred to non-experimental breeding pairs which nested in a similar period but had shortly before hatching produced incomplete clutches ( 1 or 2 eggs), or whose clutches included some chicks that could not hatch (for reasons of infertile eggs or embryonic death during incubation). This induced experimental females to lay replacement clutches. We ceased feeding of the first group of birds of both species after the completion of their first clutches (group fed1), the second after completion of their replacement clutches (group fed2), while a third control group was not fed (group unfed). In this way, each of the three groups laying replacement clutches experienced different food conditions. We provided gulls with chopped freshwater fish naturally available from the Vistula River (mainly roach Rutilus rutilus; 150-160 g/ day/territory). Fish are a valuable, high-protein component of the bird's diet, and the portion size significantly exceeded the daily energy demands of adult birds of both species (see Bolton et al. 1992). Every morning, supplementary food was provided in the territory of each randomly chosen pair, in a permanent place very close to the nest. The control nest sites were visited in the same way as supplemented nests (but no supplementary food was provided). Gulls had no problem finding the place of feeding and effectively defended it against neighbours. Both parents were usually present during feeding. After 2 or 3 days, birds became accustomed to feeding and waited near the territory for extra food. Almost always, it was the female that consumed most of the food portion, while a male defended it against kleptoparasiting neighbours. Even if a large part or the entirety of the food was eaten by a male (if there was no female in the territory), a female received her portion from the male shortly after, either during numerous courtship feedings or as an invitation to copulation (Bukaciński and Bukacińska 2003, 2015a, b).

At the beginning of the breeding season, fragments of islands with nests of fed and unfed pairs were surrounded by an electric fence (see Bukaciński 2015; Bukaciński et al. 2018). Fences hampered (but did not prevent) chicks from moving too far away from the territory, at least during the first 5 days of life when their mobility was low. Most importantly, these fences prevented predation by mammals (i.e., the type of breeding losses that are unrelated to the quality and/or condition of parents or their reproductive tactics). Broods for which there was uncertainty as to how many and which chicks survived to the 5 th day after hatching were excluded from the analyses (BHG: 0 - unfed, 1 -fed1, and 2-fed2; MG: 0, 2, and 2 respectively). Chicks from these nests were last seen on the third or fourth day of life. Following this time, the chicks probably moved beyond the fence. In such cases, we did not know whether their absence during the observed parental feeding attempts was due to movement beyond the fence or the action of avian predators.

\section{Molecular methods}

We used either a phenol-chloroform method of DNA extraction (Green and Sambrook 2012) or a GeneMatrix Quick Tissue DNA Purification Kit (EURx) for tissue samples. A salting-out procedure (Miller et al. 1988) or a GeneMatrix Quick Blood DNA Purification Kit (EURx) was used for blood samples. For sex determination, we applied a method 
based on amplification of the CHD1 gene intron (Chromohelicase-DNA-binding gene) using $2550 \mathrm{~F}$ and $2718 \mathrm{R}$ primers (Fridolfsson and Ellegren 1999; Ležalova et al. 2005). The $25 \mu \mathrm{l}$ PCR reaction mixture contained $2.5 \mu 1$ 10xPCR buffer (EURx), $1.5 \mu \mathrm{l} 25 \mathrm{mM} \mathrm{MgCl}_{2}$ (EURx), $200 \mu \mathrm{M}$ each dNTP (EURx), 30 pmol of each primer, and 1 U Taq DNA Polymerase (EURx). Approximately 50-150 ng of genomic DNA was used as a template. Polymerase chain reaction (PCR) was performed in a Biometra TOptical Gradient 96 thermal cycler. We applied the following program: an initial denaturing step at $94{ }^{\circ} \mathrm{C}$ for $1 \mathrm{~min} 30 \mathrm{~s}, 30$ cycles of $48^{\circ} \mathrm{C}$ for $45 \mathrm{~s}, 72^{\circ} \mathrm{C}$ for $45 \mathrm{~s}, 94^{\circ} \mathrm{C}$ for $30 \mathrm{~s}$, then $48^{\circ} \mathrm{C}$ for $1 \mathrm{~min}$, and final elongation at $72{ }^{\circ} \mathrm{C}$ for $5 \mathrm{~min}$ (Griffiths et al. 1998; Ležalova et al. 2005). The PCR products were separated for $30 \mathrm{~min}$ at $7-10 \mathrm{~V} / \mathrm{cm}$ using $3 \%$ agarose gel stained with ethidium bromide. Males were identified by one band and females by two bands. One known adult male and one known adult female were included in the last line of each gel, as well as a blind sample without DNA.

\section{Statistical analyses}

We modelled the variation in sex ratio of chicks of two gull species at two stages of their early lives: at hatching and when a first-hatched chick was 5 days (i.e., following the period of most intense chick mortality occurring shortly after hatching) (e.g., Bukaciński and Bukacińska 1995, 2015a, b; Bukacińska 1999; Buczyński 2000). We used the sex of the chick ( 0 , female; 1 , male) as the binary response variable and jointly analysed data from two study species to look for possible between-species differences. We analysed variation in the response variable (effectively, the probability of the chick being male) as a function of three possible predictors: feeding treatment of the parent female prior to laying the replacement clutch, egg position in the laying sequence, and identity of the species. Treatment was coded as a factor with three levels: unfed (control), fed until laying of first clutch (fed1), and fed until laying of replacement clutch (fed2). Egg position in the laying sequence was coded as a factor with three levels: A-egg (first-laid), B-egg (second), and C-egg (third). Species were coded as another factor with two levels (Mew Gull, MG; Black-headed Gull, BHG).

To analyse factors accounting for possible changes in the sex ratio between hatching and the 5th day of life, we analysed survival of chicks until the 5 th day ( 0 , died; 1 , survived; binary response) as a function of four predictors: treatment, egg position in the laying sequence, species identity, and sex of the chick.

We employed generalized linear mixed models (GLMMs) with a binomial error structure and logit link function to model a relationship between the sex of a focal chick and three candidate predictors in addition to the survival of a chick and four candidate predictors. We applied an information-theoretic approach (Burnham and Anderson 2002) to find the most parsimonious model among the candidate model set, starting from the most complex (global) model and including all possible simpler models (Grueber et al. 2011). Multiple competing models (with various predictors) were assessed for their fit to the data using Akaike's information criterion corrected for finite samples (AICc). The model selection procedure began from the global model, which included all fixed predictors as main terms and all their two-way interactions (Bolker et al. 2009). We did not use three-way interactions as they are minimally interpretable. This resulted in 18 (chick sex) or 113 (chick survival) models being ranked initially using the AICc criterion. Brood identity (female identity) was included in all models as a random factor. We used $\mathrm{R}$ environment ( $\mathrm{R}$ Core Team 2017) and fit GLMMs with the lme4 package (Bates et al. 2015). The MuMIn package (Bartoń 2017) was used to screen all possible subset models of the global model.

Models differing by less than 6 AICc units from the topranked model were initially considered as equally informative (Richards 2008; Richards et al. 2011) and were averaged to obtain parameter estimates and their $95 \%$ CIs, while the remaining lower-ranked models were discounted. A natural or conditional averaging method (as opposed to a zero or full method) was applied to obtain weighted parameter estimates across the candidate model set. We then used a "nesting rule" (Harrison et al. 2018) to discount all models that were a more complex version of simpler models having a higher AICc in the candidate model set (Richards 2008, 2015; Richards et al. 2011). For the purpose of transparency, we report these models in tables showing the results of model selection (Tables 3, 5, 7). In addition, we used relative variable importance (RVI) and 95\% CIs of model-averaged parameter estimates to decide if a candidate model with a reasonable evidence ratio (usually between 2.5 and 3.5 in our analyses), as compared with the top-ranked model, should be kept in the set of best AIC models (Burnham and Anderson 2002; Anderson 2008). Relative variable importance was used here as a supplementary guide, measuring predictor criticality, rather than true importance (Azen et al. 2001; Galipaud et al. 2017). Candidate models containing "pretending" variables (Anderson 2008; Arnold 2010) were discounted earlier in the analysis using the more stringent Richards (2008) criteria. Applying all of these criteria resulted in the retention of the top model as the sole basis for inference in all three model selection procedures conducted here. We used an effects package to estimate fixed factors effects (average model predictions or estimated marginal means) and their 95\% confidence intervals (Fox 2003) for the final model.

With respect to experimental group differences, a oneway analysis of variance (ANOVA) was used to check for differences in time-of-breeding and a chi-square test was employed to detect differences in frequencies of broods with 
Table 3 Summary of model selection results for GLMMs explaining variation in sex ratio (probability of chick being male), recorded in replacement clutches of two gull species at hatching

\begin{tabular}{|c|c|c|c|c|c|c|}
\hline No & Model (fixed parameters) & $d f$ & LL & AICc & $\Delta \mathrm{AICc}$ & Weight \\
\hline 1 & Treatment + egg + species + treatment species & 9 & -509.143 & 1036.5 & 0.00 & 0.527 \\
\hline (2) & Treatment + egg + species + treatment:species + egg:species & 11 & -507.590 & 1037.5 & 0.99 & 0.321 \\
\hline (3) & Treatment + egg + species + treatment:species + treatment:egg & 13 & -507.217 & 1040.9 & 4.38 & 0.059 \\
\hline (4) & $\begin{array}{l}\text { Treatment }+ \text { egg }+ \text { spe- } \\
\text { cies + treatment:species + treatment:egg + egg:species }\end{array}$ & 15 & -505.647 & 1041.9 & 5.39 & 0.036 \\
\hline 5 & Treatment+egg & 6 & -515.013 & 1042.1 & 5.61 & 0.032 \\
\hline
\end{tabular}

For each model, $\mathrm{df}$ is the number of estimated parameters, LL is the model log-likelihood, AICc is the Akaike's information criterion corrected for small samples, $\triangle \mathrm{AICc}$ is the difference between model's AICc value and the minimum AICc for the whole set of 18 competing models, and weight is Akaike weight for a model. Only models within 6 AICc units from the top model are listed, in ascending order of $\Delta$ AICc. For each model, no. $=$ model number, treatment $=$ feeding treatment, species $=$ Mew Gull or Black-headed Gull, egg = egg position within laying sequence. All models had a binomial error structure, with the identity of a brood entered as a random factor. Models that represent more complex versions of simpler models with a lower AICc (and as such should not be considered as the most parsimonious models; see text: "Statistical methods") are indicated with brackets around the model number

variable chick mortality (SPSS 11.0 for Windows; SPSS Inc., Chicago, USA).

Only clutches with a known chick origin (from A-, B-, or C- egg) were included in the analysis ( $n=149$ and $n=114$ nests of BHGs and MGs, respectively).

\section{Results}

\section{Phenology of first and replacement egg-laying}

All 149 BHG pairs produced a replacement clutch $12.6 \pm 2.5$ days (mean $\pm \mathrm{SD}$ ) after their first clutch was experimentally removed. This time interval was not affected by the feeding treatment (one-way ANOVA, $F_{2,146}=0.81$, $p=0.37$ ). Mean laying dates of first (April $21 \pm 5.1$ days) and replacement clutches (May $2 \pm 5.6$ days) did not differ between feeding treatments (one-way ANOVA, $F_{2,146}=0.66$, $p=0.42$, and $F_{2,146}=0.37, p=0.54$, respectively).

Similarly, in the case of MG pairs, we did not find any differences among the experimental groups with respect to the date of laying. All 114 pairs produced a replacement clutch on average $12.3 \pm 3.0$ days after their first clutch was experimentally removed. This time interval did not differ among feeding treatments (one-way ANOVA, $F_{2,111}=0.30$, $p=0.59$ ). Likewise, the mean laying dates of first (May $7 \pm 5.8$ days) and replacement clutches (May $23 \pm 6.0$ days) did not differ among feeding treatments (one-way ANOVA, $F_{2,111}=0.36, p=0.55$, and $F_{2,111}=0.53, p=0.47$, respectively).

Due to the fact that we did not record any losses at the incubation stage, there were three eggs in all replacement clutches on the day of hatching, and primary (i.e., during egg laying) and secondary (i.e., shortly before hatching) sex ratios were the same.

\section{Hatching sex ratio}

Sex ratio at hatching was affected by our experimental treatment, with additional effects of egg sequence and species identity. The best-supported model of hatching sex ratio included egg sequence, species, treatment, and species $\times$ treatment interaction as fixed predictors (Table 3 ). Apparently, there was some support for the additional effect of species $\times$ egg sequence, as evidenced by the second-ranked model (evidence ratio 1.64). However, this model was only a more complex version of the top model and model-averaged estimates for this interaction overlapped zero (Table 4), prompting us to discount the possibility that the egg sequence effect differed between species. Likewise, there was no compelling evidence to support inclusion of egg $\times$ treatment interaction as a truly informative parameter (all model-averaged $95 \%$ CIs overlapped zero, RVI =0.10). Therefore, we adopted the AICbest model (Table 3 ) as the basis of our inference.

For both gull species, parents that were provided supplemental food had more male chicks at hatching than unfed (control) parents. This was particularly so if they were fed until laying of the replacement clutch. This gradient in hatching sex ratio was much more pronounced in MG than in BHG (Fig. 1), with $69 \%$ of male chicks in broods of MG parents fed until laying of the replacement clutch and $27 \%$ of male chicks of MG parents not receiving supplemental food (56\% vs. $41 \%$, respectively, in BHG).

In both gull species, male chicks were also clearly more frequently represented in A-eggs (61\%) than in B- or C-eggs (39\% and 46\%, respectively; Fig. 2). Despite the lack of convincing evidence to support the inclusion of egg $\times$ experiment interaction as a truly informative parameter (see above), we nevertheless present this relationship in Fig. 3. It provides a useful background to explain the mortality rate 
Table 4 Model-averaged parameter estimates for the most parsimonious set of candidate GLMMs explaining variation in sex ratio (probability of chick being male) at hatching

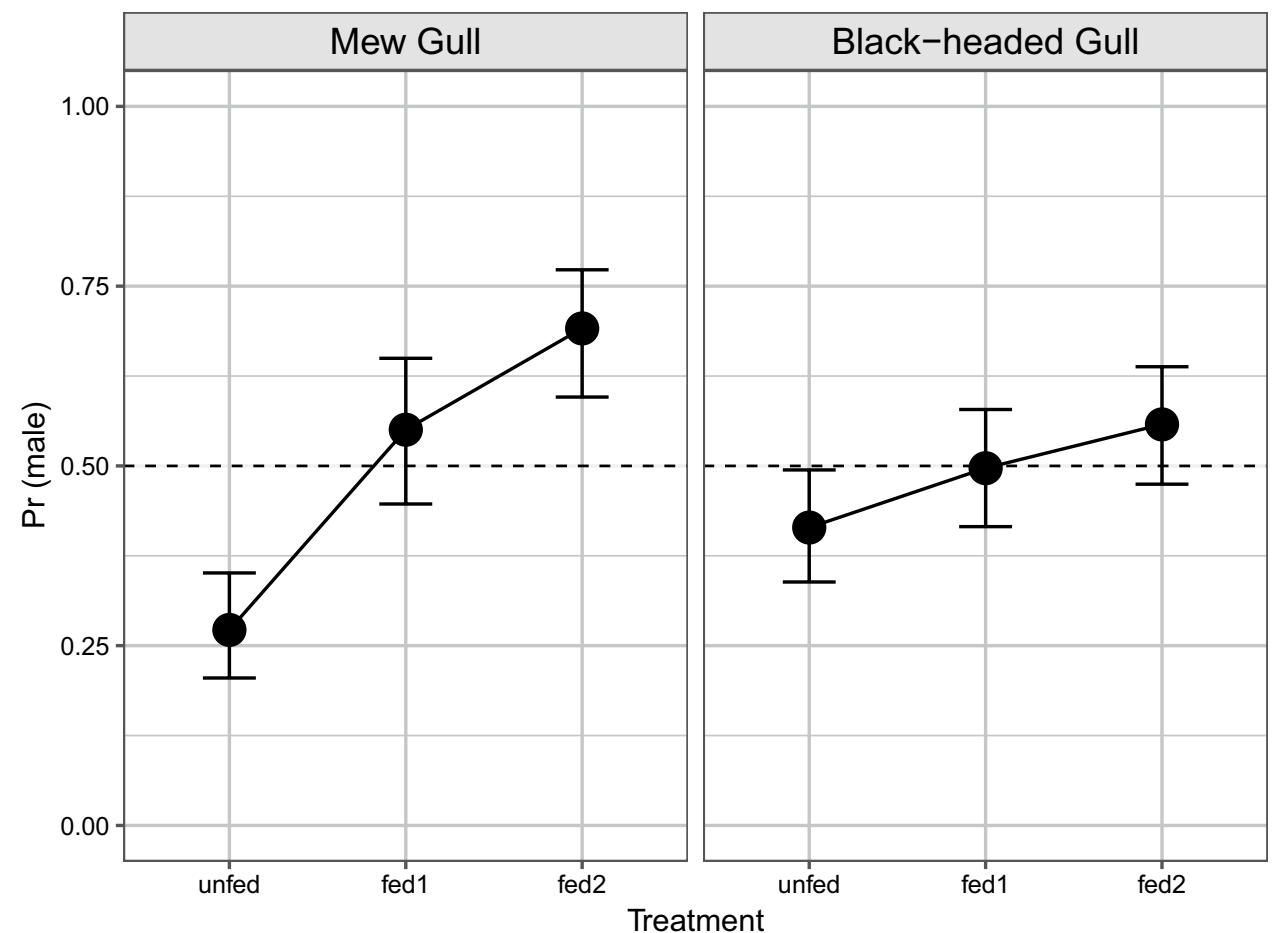

\begin{tabular}{|c|c|c|c|c|}
\hline \multirow[t]{2}{*}{ Parameter } & \multirow[t]{2}{*}{ Estimate } & \multirow[t]{2}{*}{ SE } & \multicolumn{2}{|l|}{$95 \% \mathrm{CI}$} \\
\hline & & & lower & upper \\
\hline Intercept & -0.4701 & 0.2359 & -0.9330 & -0.0072 \\
\hline Egg (B) & -0.4701 & 0.2359 & -1.3279 & -0.2846 \\
\hline Egg (C) & -0.7038 & 0.2745 & -1.2424 & -0.1652 \\
\hline Species (BHG) & 0.6499 & 0.2803 & 0.0996 & 1.2001 \\
\hline Treatment (fed1) & 1.1602 & 0.3048 & 0.5621 & 1.7584 \\
\hline Treatment (fed2) & 1.7227 & 0.3401 & 1.0553 & 2.3901 \\
\hline Species (BHG): treatment (fed1) & -0.8520 & 0.3694 & -1.5771 & -0.1268 \\
\hline Species (BHG): treatment (fed2) & -1.2078 & 0.3716 & -1.9372 & -0.4785 \\
\hline Egg (B): species (BHG) & 0.3808 & 0.3757 & -1.1183 & 0.3567 \\
\hline Egg (C): species (BHG) & 0.2754 & 0.3742 & -0.4591 & 1.0099 \\
\hline Egg (B): treatment (fed1) & 0.0487 & 0.4476 & -0.8300 & 0.9273 \\
\hline Egg $(C)$ : treatment (fed1) & 0.2985 & 0.4450 & -0.5751 & 1.1721 \\
\hline Egg (B): treatment (fed2) & 0.4589 & 0.4448 & -0.4143 & 1.3321 \\
\hline Egg $(C)$ : treatment (fed2) & 0.8621 & 0.4477 & -0.0167 & 1.7409 \\
\hline
\end{tabular}

Shown are conditional estimates of fixed effects averaged across 5 candidate models with $\Delta$ AICc $<6$ (see

Table 3). Estimates with 95\%CIs not overlapping zero are shown in bold
Fig. 1 Probability of a chick being male at hatching in relation to feeding treatment (unfed-parents receiving no supplemental feed, fed 1 - parents fed until laying of first clutch, fed2-parents fed until laying of replacement clutch, and species (panels). Modelled means with $\pm 95 \%$ confidence intervals from the top-ranked model (Table 3) are shown, based on values extracted from the effects package 


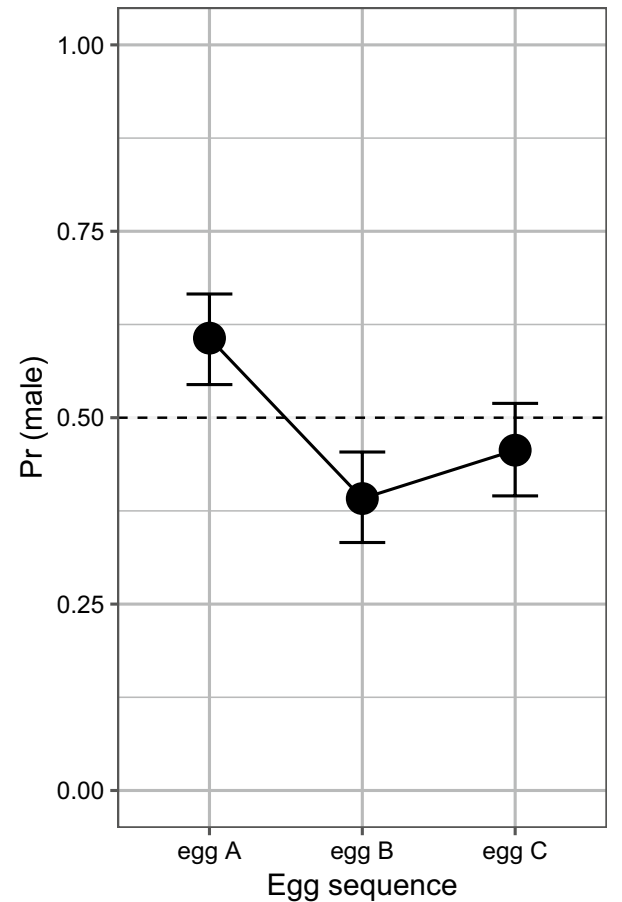

Fig. 2 Probability of a chick being male at hatching in relation to egg position in the laying sequence (egg A: first-laid egg, egg B: secondlaid egg, egg C: third-laid egg). Modelled means with $\pm 95 \%$ confidence intervals from the top-ranked model (Table 3 ) are shown, based on the values extracted from the effects package for this variable in the full model set was very low (0.46). Furthermore, models including species effect, alongside with species $\times$ treatment effect, represented cases of nesting issues in model selection (see: Statistical methods). This suggested that they should be removed from the candidate set of best models. In addition, the species variable included in the second-best model met the criteria of a "pretending variable" (Anderson 2008; Arnold 2010), with almost the same associated model log-likelihood as the top model $(-369.535$ vs. -369.571$)$ and with a difference in AICc close to two (1.98). We, therefore, conclude that treatment and egg sequence are the single best predictors of sex ratio among 5-day-old chicks of both gull species.

As at the time of hatching, on the fifth day of life the brood sex-ratio was clearly male-biased in parents receiving supplemental feeding in both gull species. However, differences between treatments were less extreme than at hatching. Broods of gull parents receiving supplemental food until laying of a replacement clutch contained 55\% male chicks, while among unfed parents this proportion averaged $40 \%$ (Fig. 4).

In both gull species, chicks who survived until the 5th day of life and hatched from first-laid eggs (A-eggs) were predominantly male (62\%), whereas chicks from B- and C-eggs were mostly female ( $40 \%$ and $44 \%$ male, respectively; Fig. 5). These results were independent of feeding treatment.
Fig. 3 Probability of chick being male at hatching in relation to egg position in the laying sequence (egg A: first-laid egg, egg B: second-laid, egg C: third-laid egg) and to feeding treatment (unfed-parents receiving no supplemental feed, fed 1 -parents fed until laying of first clutch, fed2-parents fed until laying of replacement clutch). Modelled means with $\pm 95 \%$ confidence intervals from the third-ranked model (Table 3) are shown, based on the values extracted from the effects package
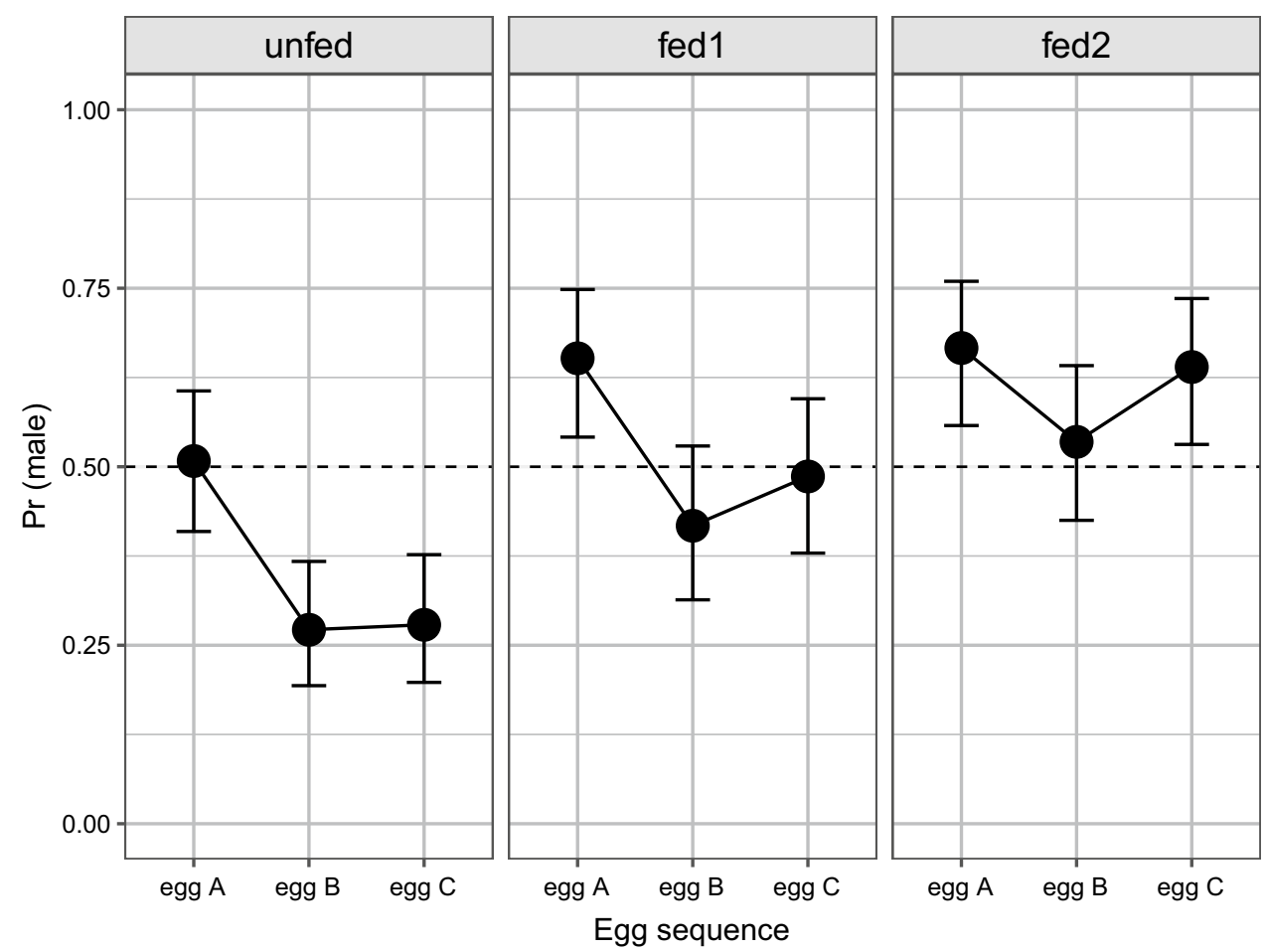
Table 5 Summary of model selection results for GLMMs explaining variation in sex ratio (probability of chick being male), recorded in replacement clutches of two gull species at 5 days post hatching
Table 6 Model-averaged parameter estimates for the mos parsimonious set of candidate GLMMs explaining variation in sex ratio (probability of chick being male) at 5 days posthatching

\begin{tabular}{llrrrrr}
\hline No & Model (fixed parameters) & $d f$ & LL & AICc & $\Delta$ AICc & Weight \\
\hline 1 & Treatment + egg & 6 & -369.571 & 751.3 & 0.00 & 0.462 \\
$(2)$ & Treatment + egg + species & 7 & -369.535 & 753.3 & 1.98 & 0.172 \\
$(3)$ & Treatment + egg + species + egg:species & 9 & -367.594 & 753.5 & 2.22 & 0.152 \\
4 & Egg & 4 & -373.588 & 755.2 & 3.95 & 0.064 \\
$(5)$ & Treatment + egg + species + treatment:species & 9 & -368.791 & 755.9 & 4.62 & 0.046 \\
(6) & Treatment + egg + spe- & 11 & -366.808 & 756.1 & 4.81 & 0.042 \\
& $\quad$ cies + treatment:species + egg:species & & & & & \\
(7) & Egg + species & 5 & -373.579 & 757.3 & 5.97 & 0.023 \\
\hline
\end{tabular}

For each model, $\mathrm{df}$ is the number of estimated parameters, LL is the model log-likelihood, AICc is the Akaike's information criterion corrected for small samples, $\triangle \mathrm{AICc}$ is the difference between model's AICc value and the minimum AICc for the whole set of 18 competing models, and weight is Akaike weight for a model. Only models within 6 AICc units from the top-model are listed (in ascending order of $\Delta$ AICc). For each model, no. $=$ model number, treatment $=$ feeding treatment, species $=$ Mew Gull or Black-headed Gull, egg = egg position within laying sequence. All models had a binomial error structure, with identity of brood entered as random factor. Models that represent more complex versions of simpler models with a lower AICc (and as such should not be considered as the most parsimonious models; see text: "Statistical methods") are indicated with brackets around the model number

\begin{tabular}{|c|c|c|c|c|}
\hline \multirow[t]{2}{*}{ Parameters } & \multirow[t]{2}{*}{ Estimate } & \multirow[t]{2}{*}{ SE } & \multicolumn{2}{|l|}{$95 \% \mathrm{CI}$} \\
\hline & & & Lower & Upper \\
\hline Intercept & -0.4761 & 0.2344 & -0.9361 & -0.0162 \\
\hline Egg (B) & -0.7917 & 0.2521 & -1.2864 & -0.2970 \\
\hline $\operatorname{Egg}(C)$ & -0.6683 & 0.2413 & -1.1418 & -0.1948 \\
\hline Species (BHG) & 0.6332 & 0.2937 & 0.0567 & 1.2098 \\
\hline Treatment (fed1) & 1.1575 & 0.3004 & 0.5679 & 1.7471 \\
\hline Treatment (fed2) & 1.7481 & 0.3230 & 1.1144 & 2.3818 \\
\hline Species (BHG): treatment (fed1) & -0.8501 & 0.3691 & -1.5746 & -0.1256 \\
\hline Species (BHG): treatment (fed2) & -1.2072 & 0.3715 & -1.9364 & -0.4779 \\
\hline Egg (B): species (BHG) & -0.3806 & 0.3759 & -1.1185 & 0.3574 \\
\hline Egg $(\mathrm{C})$ : species $(\mathrm{BHG})$ & 0.2752 & 0.3739 & -0.4589 & 1.0092 \\
\hline
\end{tabular}

Shown are conditional estimates of fixed effects averaged across 7 candidate models with $\Delta$ AICc $<6$ (see Table 5). Estimates with 95\%CIs not overlapping zero are shown in bold

\section{Survival during the first 5 days post-hatching}

The top-ranked model revealed that chick survival during the first 5 days of life was primarily dependent on sex, species, egg sequence, and treatment (with an added effect of sex $\times$ treatment interaction) (Table 7). The model ranked as second-best differed in that it lacked a species variable and inclusion of this predictor was not supported by modelaveraged effects (95\% CIs included zero; Table 8). However, this predictor showed an acceptable RVI (0.77) and no nested model lacking this predictor had a higher AICc. We, therefore, treated species as an informative variable, unlike a number of interactions appearing in lower-ranked models that were discounted because of the presence of simpler, nested models with a lower AICc.

Chicks hatched from a last-laid (C) egg in a clutch had a much lower probability of survival (39\%) than chicks from the first two eggs (A-egg 97\%, B-egg 91\%), irrespective of sex, treatment, or species (Fig. 6). Supplementary feeding was associated with improved chick survival for both gull species, though this effect was dependent on chick gender (Fig. 7). In control broods, in which parents did not receive any food, male chicks survived better than female chicks (77\% vs. $61 \%$ ), but the opposite was true for broods, where parents received food. In broods tended by parents fed until laying of the first clutch, male chicks had lower survival than female chicks ( $83 \%$ vs. $91 \%$ ). Similarly, broods with parents fed until laying of a replacement clutch showed the highest rates of survival compared to any other treatment; however, males survived less frequently than females ( $87 \%$ vs. $98 \%$ ). There was an overall tendency for higher survival of BHG chicks compared to MG chicks ( $88 \%$ vs. $81 \%$ ).

In all experimental groups, the frequency of broods with chicks lost in the early chick period was uneven 


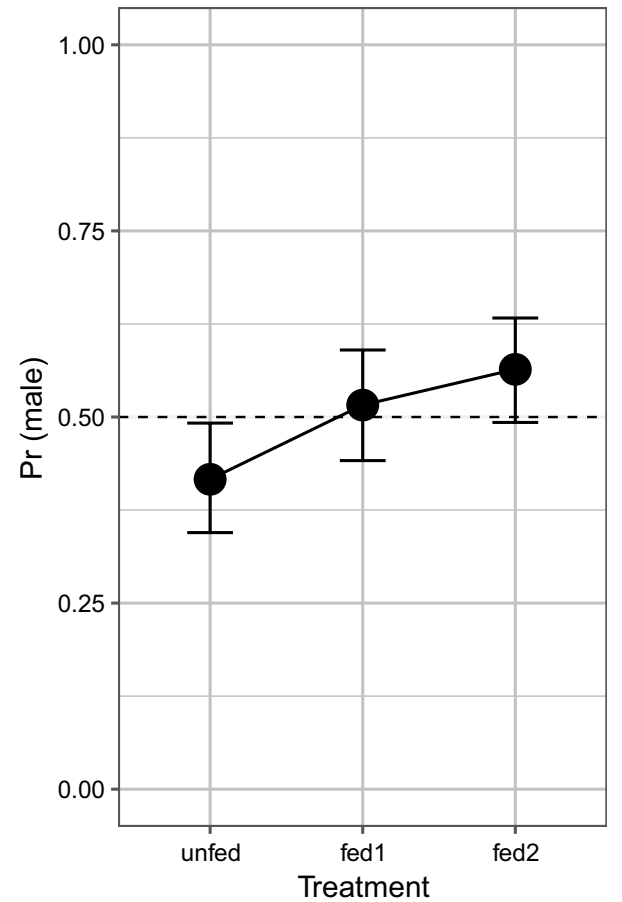

Fig. 4 Probability of chick being male at the 5th day post-hatching in relation to feeding treatment (unfed-parents receiving no supplemental feeding, fed1-parents fed until laying of first clutch, fed2parents fed until laying of replacement clutch). Modelled means with $\pm 95 \%$ confidence intervals from the top-ranked model (Table 5) are shown, based on the values extracted from the effects package

$\left(\chi_{3}^{2}=11.84-41.68, p<0.001\right.$, depending on the treatment $)$. Broods with no losses during the first 5 days post-hatching were most frequently represented among the experimental group whose parents were fed until laying of the replacement clutch, while the opposite was true for unfed parents (50.6\% and $22.0 \%$, respectively; $\chi_{3}^{2}=12.22, p=0.002$; Fig. $8 \mathrm{a}$ ). When parents lost their offspring, it was most common to lose one chick (as was the case in $43.3-52.5 \%$ of all broods, depending on the treatment), whereas total losses were recorded relatively more often in broods of control pairs (unfed) as compared to broods of fed parents $(13.0 \%, 3.8 \%$, and $6.0 \%$, for the unfed, fed 1 and fed2 groups, respectively; $\chi_{6}^{2}=52.47, p \ll 0.001$; Fig. 8a).

In broods of control pairs in which no chicks survived, male chicks prevailed in only $23.1 \%$ of them, while in the broods of parents fed until laying of a replacement clutch, male chicks prevailed in all of them, including $80 \%$ of cases in which all three chicks were male $\left(\chi_{2}^{2}=8.85, p=0.01\right.$; Fig. $\left.8 b\right)$.

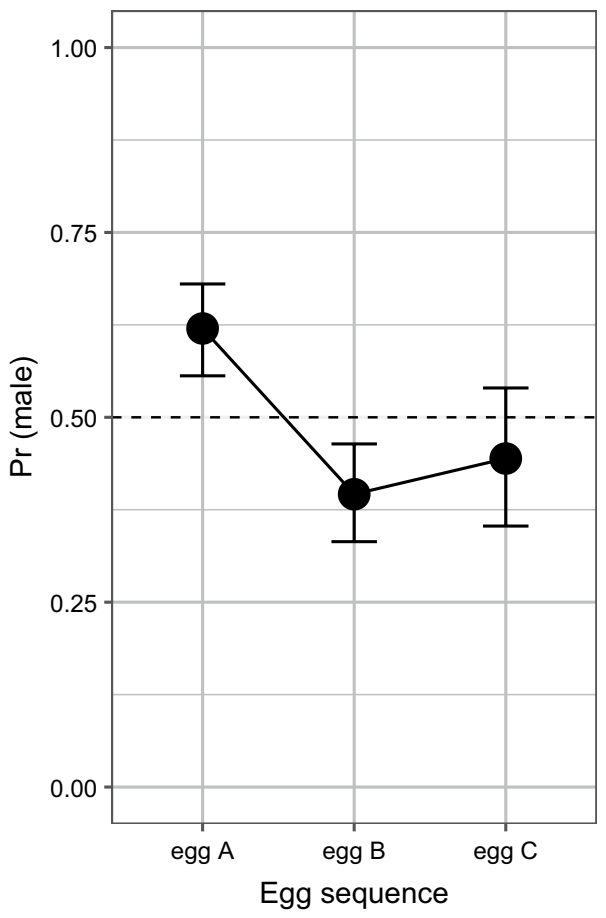

Fig. 5 Probability of chick being male at the 5th day post-hatching in relation to egg position in the laying sequence (egg A: first-laid egg, egg B: second-laid egg, egg C: third-laid egg). Modelled means with $\pm 95 \%$ confidence intervals from the top-ranked model (Table 3 ) are shown, based on the values extracted from the effects package

\section{Discussion}

\section{Replacement clutches: an indicator of good parental quality, reproductive tactics, or environmental constraint?}

Egg production is one of the most expensive components of parental effort in birds and affects the body condition of mothers (e.g., Bolton et al. 1992; Bauch et al. 2010). In the Lesser Black-backed Gull, the laying of one extra egg above the standard three results in a 5-6\% decrease in body weight and protein reserves (Monaghan et al. 1998). Renesting for gulls is, therefore, a difficult and risky action, especially because their current reproductive investment can affect future reproductive output, survival, and fitness (Monaghan et al. 1998; Nager et al. 2001; Kalmbach et al. 2004). Renesting is considered an indicator of the good quality and/or condition of parents (Roonem and Robertson 1997; Hipfner et al. 1999; Wendeln et al. 2000; Becker and Zang 2011). This behaviour can also be associated with more extensive parental experience and/or older age (Wooller 1980; Wendeln et al. 2000; Arnold et al. 2010). In the BHG and MG colonies of the Vistula River (as well as in other breeding grounds), the oldest/most experienced and/or good-quality birds begin breeding first (Onno 1967; Kharitonov 1975; 
Table 7 Summary of model selection results for GLMMs explaining probability of chick surviving until 5th day post-hatching, recorded in replacement clutches of two gull species

\begin{tabular}{|c|c|c|c|c|c|c|}
\hline No & Model (fixed parameters) & $d f$ & LL & $\mathrm{AICc}$ & $\Delta \mathrm{AICc}$ & Weight \\
\hline 1 & Treatment + egg + species + sex + treatment:sex & 10 & -348.114 & 716.5 & 0.00 & 0.355 \\
\hline 2 & Treatment + egg + sex + treatment:sex & 9 & -349.757 & 717.7 & 1.23 & 0.191 \\
\hline (3) & Treatment + egg + species + sex + treatment:sex + species:sex & 11 & -347.983 & 718.3 & 1.79 & 0.145 \\
\hline (4) & Treatment + egg + species + sex + treatment:sex + egg:species & 12 & -347.799 & 720.0 & 3.49 & 0.062 \\
\hline$(5)$ & Treatment + egg + species + sex + treatment:sex + egg:sex & 12 & -347.984 & 720.4 & 3.86 & 0.052 \\
\hline$(6)$ & Treatment + egg + species + sex + treatment:sex + treatment:species & 12 & -348.351 & 721.1 & 4.59 & 0.036 \\
\hline (7) & Treatment + egg + sex + treatment:sex + egg:sex & 11 & -349.619 & 721.6 & 5.07 & 0.028 \\
\hline$(8)$ & Treatment + egg + species + sex + treatment:sex + species:sex + egg:species & 13 & -347.697 & 721.9 & 5.35 & 0.024 \\
\hline (9) & Treatment + egg + species + sex + treatment:sex + species:sex + egg:sex & 13 & -347.920 & 722.3 & 5.80 & 0.020 \\
\hline
\end{tabular}

For each model, $\mathrm{df}$ is the number of estimated parameters, LL is the model log-likelihood, AICc is the Akaike's information criterion corrected for small samples, $\triangle \mathrm{AICc}$ is the difference between model's AICc value and the minimum AICc for the whole set of 113 competing models, and weight is Akaike weight for a model. Only models within 6 AICc units from the top model are listed, in ascending order of $\Delta$ AICc. For each model, no. $=$ model number, treatment $=$ feeding treatment, species $=$ Mew Gull or Black-headed Gull, egg $=$ egg position within laying sequence, $\operatorname{sex}=\operatorname{sex}$ of the chick $(0$, female; 1 , male). All models had the binomial error structure, with identity of brood entered as random factor. Models that represent more complex versions of simpler models with a lower AICc (and as such should not be considered as the most parsimonious models; see text: "Statistical methods") are indicated with brackets around the model number

Table 8 Model-averaged parameter estimates for the most parsimonious set of candidate GLMMs explaining probability of chick surviving until 5th day post-hatching

\begin{tabular}{|c|c|c|c|c|}
\hline \multirow[t]{2}{*}{ Parameter } & \multirow[t]{2}{*}{ Estimate } & \multirow[t]{2}{*}{ SE } & \multicolumn{2}{|l|}{$95 \% \mathrm{CI}$} \\
\hline & & & Lower & Upper \\
\hline Intercept & 1.8436 & 0.4264 & 1.0067 & 2.6804 \\
\hline Egg (B) & -1.0788 & 0.3574 & -1.7804 & -0.3773 \\
\hline $\operatorname{Egg}(C)$ & -3.8652 & 0.4689 & -4.7857 & -2.9447 \\
\hline Sex (male) & 0.7835 & 0.4469 & -0.0938 & 1.6607 \\
\hline Species (BHG) & 0.5105 & 0.3823 & -0.2400 & 1.2609 \\
\hline Treatment (fed1) & 1.7917 & 0.4747 & 0.8599 & 2.7235 \\
\hline Treatment (fed2) & 3.2652 & 0.6172 & 2.0536 & 4.4768 \\
\hline Sex (male): treatment (fed1) & -1.4113 & 0.6049 & -2.5986 & -0.2239 \\
\hline Sex (male): treatment (fed2) & -2.5917 & 0.6932 & -3.9524 & -1.2310 \\
\hline Sex (male): species (BHG) & 0.2543 & 0.4963 & -0.7200 & 1.2286 \\
\hline Egg (B): species (BHG) & 0.2700 & 0.6288 & -0.9643 & 1.5043 \\
\hline Egg (C): species (BHG) & -0.1530 & 0.6118 & -1.3540 & 1.0479 \\
\hline Egg (B): sex (male) & -0.2685 & 0.6791 & -1.6016 & 1.0646 \\
\hline $\operatorname{Egg}(\mathrm{C})$ : sex (male) & -0.3413 & 0.6542 & -1.6256 & 0.9429 \\
\hline Species (BHG): treatment (fed2) & -0.0205 & 0.6803 & -1.3559 & 1.3149 \\
\hline Species (BHG): treatment (fed2) & 0.1218 & 0.6951 & -1.2427 & 1.4863 \\
\hline
\end{tabular}

Shown are conditional estimates of fixed effects averaged across 9 candidate models with $\Delta$ AICc $<6$ (see Table 7). Estimates with 95\% CIs not overlapping zero are shown in bold
Fjeldsa 1978; Rattiste and Lillleleht 1987; Różycki 2014). Considering that all experimental pairs began laying their first clutches no later than during the peak of the laying season, it is quite likely that most of them belonged to the fraction of the oldest and most experienced birds.

However, it is problematic to assume that under the Vistula River conditions, the individual characteristics of a bird have a key impact on the decision to lay a replacement clutch (and determine the frequency of such behaviour in the population). Which and how many gulls will renest is a function of timing and the magnitude of spring floods on the Vistula River and the temporal/spatial variation in mammalian predation of first clutches. In each of the last 16 breeding seasons (2000-2015), on average nearly $90 \%$ of MG pairs and ca. $60 \%$ of BHG pairs lost their first clutches. Of these, up to 77-98\% laid a replacement clutch (Table 2). It cannot be assumed that such a large fraction was represented only by the highest quality, most experienced, and oldest birds in 


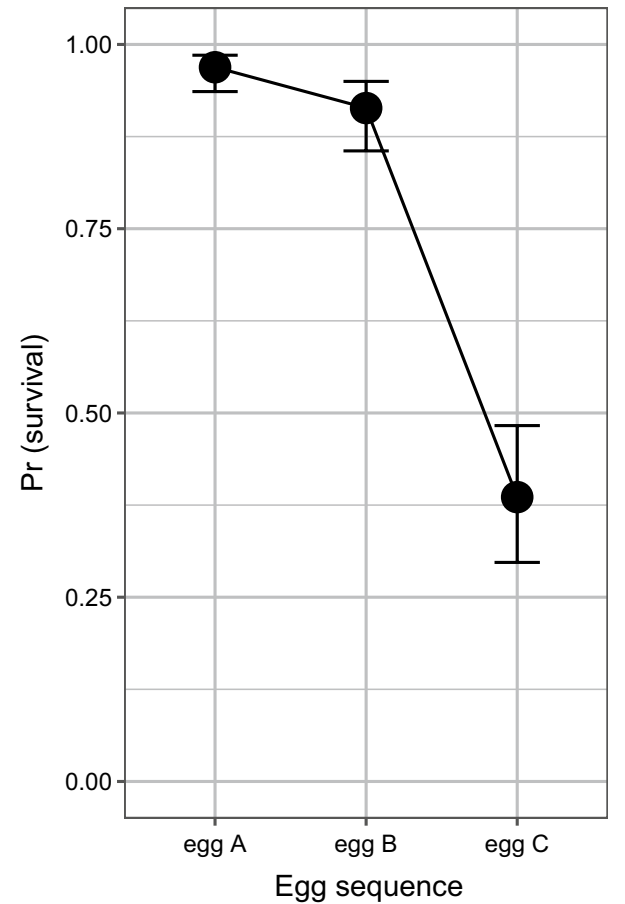

Fig. 6 Probability of chick surviving until the 5th day post-hatching in relation to egg position in the laying sequence (egg A: first-laid egg, egg B: second-laid egg, egg C: third-laid egg). Modelled means with $\pm 95 \%$ confidence intervals from the top-ranked model (Table 7) are shown, based on the values extracted from the effects package the populations of both species. A large proportion of breeding losses was the result of flooding, at which time birds lost their clutches and then engaged in synchronous re-laying of eggs. There is a possibility that for some pairs (in the case of either young and/or inexperienced birds), renesting might be a kind of "contagious behaviour" induced by courtship behaviour of neighbours (see Bukacińska 1999). A similar rapid and widespread re-laying in response to flooding of first clutches has been reported for other gull and tern species (Storey 1987; Brown and Morris 1996).

Interspecies differences in the frequency of losses resulted mainly from the fact that BHGs begin their breeding season earlier and inhabit the highest islands and/or parts of islands flooded less frequently, as compared to the lower breeding sites of MGs (Bukaciński and Bukacińska 1994, 2015a, b). As was especially the case for MG, a species with high natal philopatry and very strong nesting site tenacity (Rattiste and Lilleleht 1986; Bukaciński and Bukacińska 2003, 2015a), the decision to lay a replacement clutch seems more obligatory than a choice. Failure to renest (regardless of individual features) could result in birds having only one or two further chances of successfully breeding during their lifetime. In extreme situations, there may very well be no further chances of breeding. We believe that in the Vistula River conditions, renesting individuals of MG (and perhaps also BHG) would achieve higher lifetime reproductive success (a proxy for fitness) compared to birds that refrain from renesting, similar to what has been shown for the Common Tern (Sterna hirundo) by Becker and Zang (2011).
Fig. 7 Probability of chick surviving until the 5th day post-hatching in relation to feeding treatment (unfed-parents receiving no supplemental feeding, fed 1 - parents fed until laying of first clutch, fed2-parents fed until laying of replacement clutch) and the sex of the chick. Modelled means with $\pm 95 \%$ confidence intervals from the top-ranked model (Table 7) are shown, based on the values extracted from the effects package

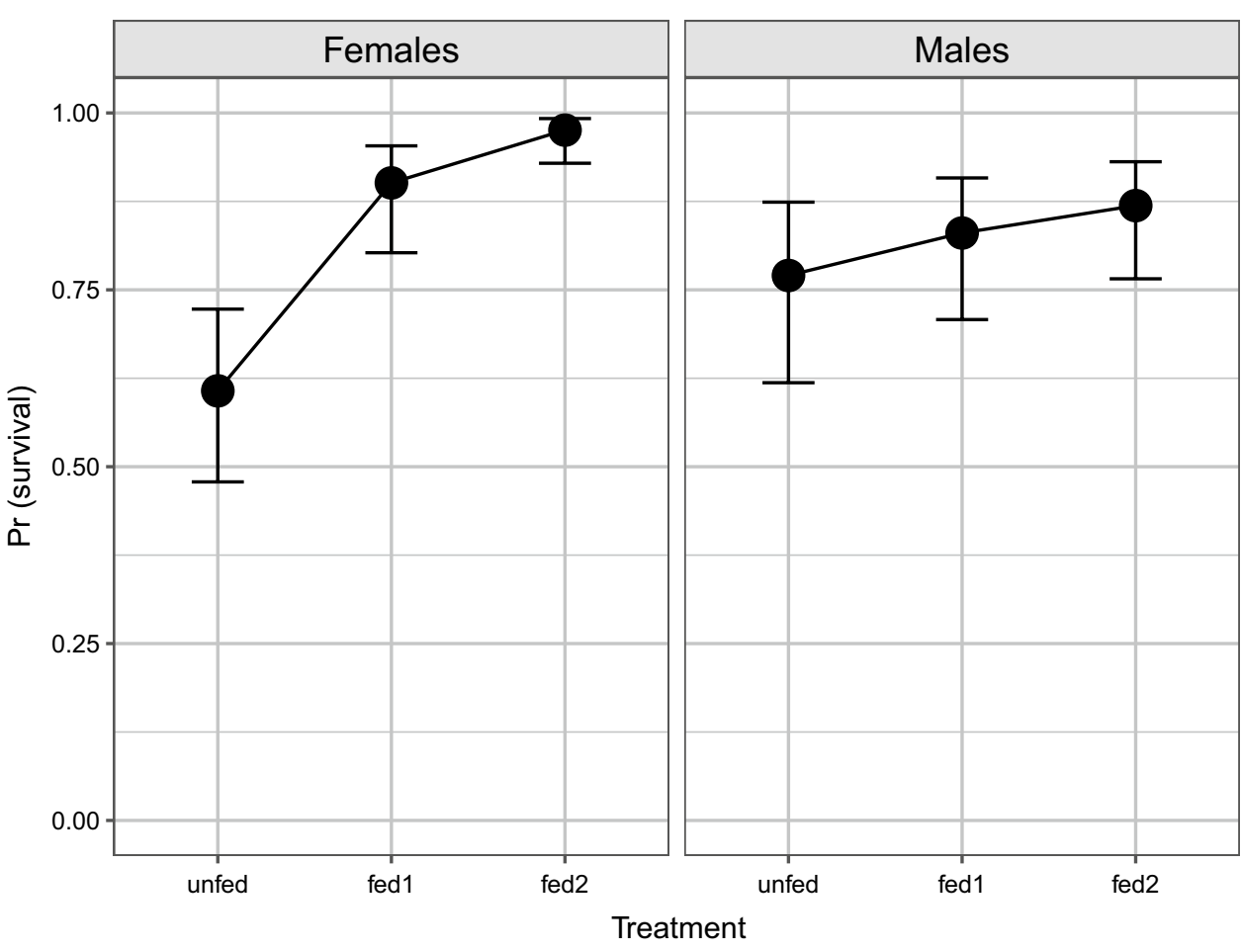



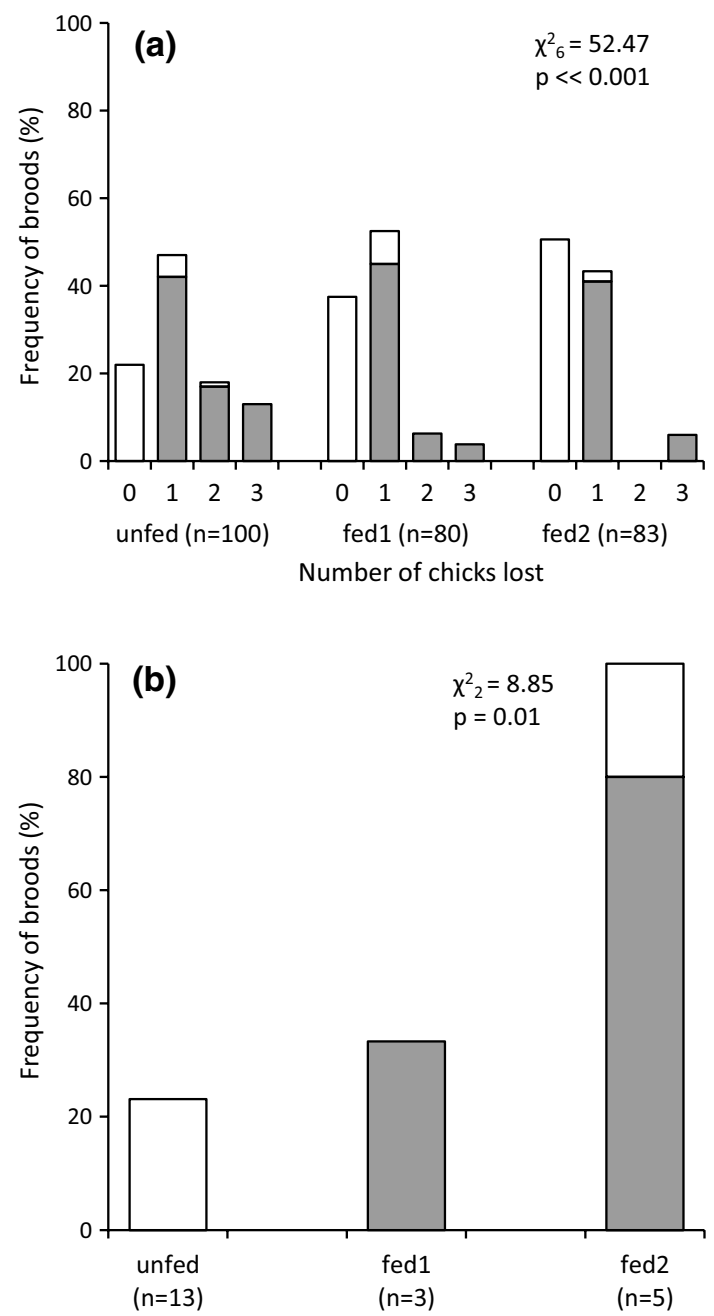

Fig. 8 Combined brood frequency (expressed as a \%) of Mew Gulls (MG) and Black-headed Gulls (BHG) having a 0, 1, 2, and 3 chicks lost between hatching and the fifth day of life (with the shaded area representing the percentage of broods in which one of the lost chicks was a C-egg) and $\mathbf{b}$ total losses (in which male chicks predominated). The shaded area represents the percentage of broods in which all chicks were males. Recall that all broods initially had three chicks. $n$ number of nests, $\chi^{2}$ chi-square test statistic, $p$ predicted probability, $* p<0.05$, other explanations as in Fig. 1

On the Vistula River, BHGs commence egg laying around mid-April and ending in the last days of May, with the peak of egg-laying occurring in the last days of April (Bukaciński and Bukacińska 1994, 2015b; Bukacińska and Bukaciński unpublished data). Mew Gulls begin egg laying in the last days of April and complete the first laying in late May or early June, with the peak of egglaying occurring between May 1 and 10 (Bukaciński and Bukacińska 1994, 2003, 2015a). Our long-term data from this population reveal that if a rise in water level destroys clutches in late April or early May (i.e., during the period when we removed the first clutches as part of our experiment), most of the BHG and almost all MG pairs usually begin to lay replacement clutches. It was, therefore, not particularly surprising that all studied pairs attempted to breed again, especially given the fact that we removed the first clutches immediately after their completion, at a time when parental investment related to incubation had just began (Bukacińska 1999; Bukaciński and Bukacińska 2003). However, we did not expect that all pairs would again lay three-egg clutches, regardless of whether and for how long they were given supplementary food. This result clearly indicates that parents prefer to lay a new, complete 3 -egg replacement clutch and adjust offspring sex ratio, than to modify parental expenses by laying fewer eggs. This is particularly interesting, because sex ratio manipulation is often considered to be only a minor adjustment of parental expenditure (and represents a smaller adjustment compared to egg-laying; see Carranza 2004; Carranza and Polo 2012). In light of this, a smaller replacement clutch would be expected. The occurrence of a large number of 3 -egg replacement clutches was likely due to the fact that such losses occurred early in the season when the most experienced and best quality birds began to breed. These birds were also in the best condition, as shown by other studies of the Vistula colonies (Różycki 2014). It is also important that the loss of a clutch occurred at a very early stage of reproduction (shortly after completion of the first clutch) when parents are more willing to lay 3-egg replacement clutches (Bukacińska 1999). Earlier data from our study site show that if a natural flood took the clutches of most BHG and MG pairs at a similar time and a similar breeding stage, then 3 -egg clutches were still predominant among replacements (although such cases accounted for only 45-70\% of clutches) (Buczyński 2000; Bukacińska 1999; Różycki 2014). The contribution of 2-egg replacement clutches ranged from 25 to $45 \%$, while those comprising one egg were never greater than a few percent (Buczyński 2000; Bukacińska 1999; Różycki 2014).

We know from previous studies that when the loss of first clutches of BHG and MG occurred later in the season and at a later breeding stage, a smaller number of pairs will lay a replacement clutch. Furthermore, the proportion of 2- and 1-egg clutches will be greater and will occur at the expense of replacement clutches containing 3 eggs (Bukacińska 1999; Różycki 2014; Bukaciński and Bukacińska unpublished data). These data show that gulls will more often reduce the size of a replacement clutch rather than forgo renesting. Taken together, these data indicate that the decision to attempt the laying of a replacement clutch might be a default behaviour rather than a strategic choice. In contrast, the number of eggs laid in such a clutch and the resulting sex-ratio of chicks appears to be more affected by the condition of parents and their reproductive tactics. 


\section{Hatching sex ratio in broods of BHGs and MGs: the effect of food availability}

Regardless of whether renesting is a choice made by higher quality birds and/or birds in better condition, a feature of the oldest and/or most experienced individuals, or is a default decision for the majority of gulls living in a highly unstable environment, expenditures incurred at the time of a first clutch (as they are related to a decrease in body mass and protein reserves in females; Monaghan et al. 1998; Wiśniewska 2014; Bukaciński and Bukacińska unpublished data) should compel parents to optimize their efforts later in the breeding season. Such considerations should also apply to primary sex-ratio biases.

The condition of parents during the period of renesting is generally poorer and the availability of food in the breeding grounds affects the level of brood sex ratio bias in both gull species. As shown by Nager et al. (1999) for Lesser Black-backed Gulls, Alonso-Alvarez and Velando (2003) and Pérez et al. (2006) for Yellow-legged Gulls (Larus cachinnans/Larus michahellis), and Merkling et al. (2012) for Black-legged Kittiwakes, we found that unfed parents overproduced daughters (i.e., the cheaper sex). In contrast, fed parents, especially those fed the longest, overproduced sons (Fig. 1). The sex ratio bias in the replacement clutches of BHGs and MGs found at hatching was in line with the theoretical predictions of the reproductive cost hypothesis (Myers 1978; Cockburn et al. 2002). Moreover, this relationship was much stronger in broods of MG, a species for which there are potentially larger differences in the costs of raising daughters and sons (as judged by body size dimorphism, though this assumption was not validated in this study). This is in contrast to broods of BHG, which are characterized by significantly less sexual size dimorphism. The much lower frequency of sons produced by unfed MG pairs might suggest that in this species (and to a greater extent than in BHGs) the larger sex may require more time and/ or nutrition/energy expenditures during the growth period, especially when parents are in poor condition (Myers 1978; Cockburn et al. 2002). This would be in agreement with the reproductive cost hypothesis.

Unlike for broods of experimentally fed BHG and Blacklegged Kittiwakes pairs, which had a balanced sex ratio at hatching (Fig. 1; Merkling et al. 2012), the broods of MG parents fed until laying of a replacement clutch (fed2) were strongly male-biased (69\% males, Fig. 1). This pattern is not inconsistent with the interpretation of the reproductive cost hypothesis, if we assume that parents in better condition (fed) are more likely to take the risk of producing offspring of the more expensive sex (i.e., the sex that is more physiologically and/or energetically demanding to produce). However, it is also consistent with the basic premise of Trivers-Willard hypothesis, given strong inter-male competition over access to best nesting sites and best mates observed in gulls in general (e.g., Southern 1981; Butler and Janes-Butler 1983; Bukacińska and Bukaciński 1993; Bukaciński and Bukacińska 1996, 2003; Bukaciński 1998). Larger size dimorphism in MG than in BHG is suggestive of more intense intra-sexual competition in the former species, resulting in greater benefits of producing good quality, competitive sons by MG in presumed best condition (fed2 group). Yet, given the data available, we cannot really offer a compelling explanation for overproduction of males by MG parents in best condition.

It is worth noting that in both Vistula gull species, sons hatched significantly more often from A-eggs (first-laid) compared to B- and C-eggs (Fig. 2). Moreover, only in A-eggs was the proportion of sons at hatching never less than 0.5 (Fig. 3). In fed pairs, the proportion of sons from each of the three eggs was higher than for unfed pairs, though the difference was greater for chicks hatched from last-laid eggs (C-eggs) compared to those hatched from either A- and B-eggs (Fig. 3). It was the most prevalent offspring sex from the first and last eggs in a brood at hatching that had the greatest impact in shaping sex bias among siblings during the chick period. Chicks from C-eggs in the Vistula River populations of MG and BHG are on average the smallest. They often hatch slightly later than offspring from A- and $\mathrm{B}$-eggs and thus are more prone to dying prematurely compared to their siblings. This is especially the case during food shortages and/or when the condition of their parents is poor (Dejtrowski 1993; Buczyński 2000; Różycki 2014). This is often the reason why chicks leave their own broodmates to join the broods of neighbours (Bukaciński et al. 2000; Bukaciński and Bukacińska 2015a, b). In contrast, the offspring from A-eggs have the highest status (usually hatching first) and generally win the competition for food with their siblings (Bukacińska 1999; Różycki 2014). In the species that produce several offspring per reproductive attempt (as with MG and BHG), parental resources must be divided among siblings. In such cases (and as Carranza (2004) has noted), the resources obtained by a single chick will depend not only on the total parental resources but also on the number and sex of competing siblings and the interactions between them (Kalmbach et al. 2005; Uller 2006). From this perspective, the optimal sex order of siblings should be arranged in a hierarchical fashion based on their expected share in parental resources, which may lead to a lack of correlation between parental resources and the brood sex ratio (Carranza 2004).

\section{Sex ratio 5 days post-hatching: the effect of sex-biased mortality}

As at hatching, on the fifth day of chick life the brood sex ratio was biased towards males among parents receiving 
supplemental food, though with two significant differences: (a) the extent of bias in MG broods was clearly smaller than at hatching, which as a consequence meant that (b) we no longer observed significant differences in this parameter between the two gull species (Fig. 4). This may indicate that sexual size dimorphism was not very important in shaping the brood sex ratio bias in MG and BHG.

Contrary to our prediction that sons will be more susceptible to poor food conditions, daughters instead experienced greater mortality. The lack of mortality differences between species in the early-chick period indicates that this relationship was stronger in MG than BHG broods. To explain this, we must take into account the following: (1) all broods of control pairs with total losses ( $13.0 \%$ of all broods) were female-biased, including almost $80 \%$ with only daughters (Fig. 8); (2) parents of all experimental groups (and both species) most often lost only one chick (60.3-87.0\% of broods with losses, depending on the experimental group), including $85.7-94.4 \%$ for which there was a chick hatched from a C-egg (Fig. 8); and (3) that among the offspring from C-eggs of unfed parents, daughters accounted for nearly $75 \%$ of chicks at hatching. There is no doubt that the key mechanism shaping this situation was competition among siblings and the condition of parents (i.e., if we accept the assumption that the poorer the condition of parents, the more daughters in the brood). More than half of the sons of control pairs hatched from A-eggs and these chicks had a probability of survival that was nearly $100 \%$. With the observation that males were produced from $30 \%$ of B-eggs [and with a probability of survival over $90 \%$ (Fig. 6)], we can see that the rank of the egg from which the offspring of a given sex hatched had a decisive impact on the overall brood sex ratio bias during the early-chick stage.

The same factors that determined higher daughter mortality in unfed (control) parents than for sons resulted in higher (as compared to daughters) son mortality in broods of fed parents, especially those fed for longer periods (Fig. 7). Among the offspring of C-eggs of this group of parents, sons comprised nearly $70 \%$ of the chicks at hatching (Fig. 3). In the control group, female-biased broods with total losses constituted the majority. In all such broods of fed 2 pairs, there were at least two sons (and in $80 \%$ of these all offspring were male) (Fig. 8). The laying order of eggs of different sexes and differential mortality of sons and daughters in the post-embryonic period shapes brood sex-ratio bias. This has been demonstrated for Lesser Black-backed Gulls, Herring Gulls Larus argentatus, and Common Terns (Nager et al. 1999, 2000a, b; Cook and Monaghan 2004; GonzálezSolís et al. 2005; Kim and Monaghan 2006).

The sex ratio bias in the broods of MG and BHG observed in this study is consistent with the theoretical predictions of the reproductive costs hypothesis (Myers 1978; Cockburn et al. 2002). Even if at the fledging stage the brood sex bias in these gull species was smaller than that of the early-chick stage, it would not necessarily mean that there is no adjustment of brood sex bias by parents. The Carranza and Polo (2012) model shows that the relationship between parental resources and brood sex ratio can be more complex than is commonly thought. Reviews that have examined the issue of brood sex ratio indicate that the condition of parents more often affects the sex of offspring in a specific position in the brood hierarchy or egg-laying sequence, rather than the sex ratio of the entire brood (Pike and Petrie 2003; AlonsoAlvarez 2006). Carranza and Polo (2012) have demonstrated that when the brood size varies widely (as is the case for MG and BHG), we should not expect a general relationship between parental expenditure and the brood sex ratio. Even in species with sexual size dimorphism, we should not predict a positive, monotonic relationship between parental expenditure and brood sex ratio; a negative relationship may be more likely instead (Carranza and Polo 2012).

Acknowledgements This study was supported by the National Science Centre, Poland (project no. N N304 1385 40). We would like to thank all of our colleagues who assisted us in the field, especially Arkadiusz Buczyński, Bartosz Jaszewski, and Marek Sawicki. We also thank two reviewers, whose insightful remarks and constructive comments have meant that the article has since acquired a completely new quality. English language was corrected by an English-speaking expert from Scribendi (Editing and Proofreading Services). We captured and marked Mew Gulls under bird ringing license no. 28/2016, issued by Ornithological Station, Museum and Institute of Zoology, Polish Academy of Sciences, based on the decision of the General Director for Environmental Protection (DZP-WG.6401.03.36.2015.km) and the Ministry of Environment (DLP-VIII-6713-21/29762/14/RN). All methods met ethical guidelines for the use of wild birds in scientific research as stipulated by Polish law. The temporary exchange of Mew Gull eggs on wooden dummies, artificial incubation of eggs in incubators, and sampling of blood and dead chicks were made under licenses from the Local Board of Ethics in Warsaw (no. 10/2015 and 11/2015) and the Regional Director for Environmental Protection in Warsaw (WPN1.6401.36.2015.EB) and Lublin (WPN.6401.25.2015.TB).

Open Access This article is licensed under a Creative Commons Attribution 4.0 International License, which permits use, sharing, adaptation, distribution and reproduction in any medium or format, as long as you give appropriate credit to the original author(s) and the source, provide a link to the Creative Commons licence, and indicate if changes were made. The images or other third party material in this article are included in the article's Creative Commons licence, unless indicated otherwise in a credit line to the material. If material is not included in the article's Creative Commons licence and your intended use is not permitted by statutory regulation or exceeds the permitted use, you will need to obtain permission directly from the copyright holder. To view a copy of this licence, visit http://creativecommons.org/licenses/by/4.0/.

\section{References}

Alonso-Alvarez C (2006) Manipulation of primary sex-ratio: an updated review. Avian Poultry Rev 17:1-20 
Alonso-Alvarez C, Velando A (2003) Female body condition and brood sex ratio in Yellow-legged Gulls Larus cachinnans. Ibis 145:220-226

Anderson DR (2008) Model based inference in the life sciences: a primer on evidence. Springer, New York

Arctander P (1988) Comparative studies on avian DNA restriction fragment length polymorphism analysis: convenient procedures based on blood samples from live birds. J Ornithol 129:205-216

Arnold TW (2010) Uninformative parameters and model selection using Akaike's information criterion. J Wildl Manag 74:1175-1178

Arnold TW, De Vries JH, Howerter DW (2010) Factors that affect renesting in mallards (Anas platyrhynchos). Auk 127:212-221

Azen R, Budescu DV, Reiser B (2001) Criticality of predictors in multiple regression. Br J Math Stat Psychol 54:201-225

Bartoń K (2017) MuMIn: multi-model inference. R package version 1.40.0. https://CRAN.R-project.org/package=MuMIn

Bates D, Maechler M, Bolker B, Walker S (2015) Fitting linear mixedeffects models using lme4. J Stat Softw 67:1-48

Bauch C, Kreutzer S, Becker PH (2010) Breeding experience affects condition: blood metabolite levels over the course of incubation in a seabird. J Comp Physiol B 180:835-845

Becker PH, Wink M (2003) Influences of sex, sex composition of brood and hatching order on mass growth in common terns Sterna hirundo. Behav Ecol Sociobiol 54:136-146

Becker PH, Zang H (2011) Renesting of common terns Sterna hirundo in the life history perspective. J Ornithol 152(Suppl 1):S213-S225

Bolker BM, Brooks ME, Clark CJ, Geange SW, Poulsen JR, Stevens MHH, White J-SS (2009) Generalized linear mixed models: a practical guide for ecology and evolution. Trends Ecol Evol 24:127-135

Bolton M, Houston D, Monaghan P (1992) Nutritional constraints on egg formation in the lesser black-backed gull: an experimental study. J Anim Ecol 61:521-532

Booksmythe I, Mautz B, Davis J, Nakagawa S, Jennions MD (2017) Facultative adjustment of the offspring sex ratio and male attractiveness: a systematic review and meta-analysis. Biol Rev 92:108-134

Boulet M, Olsen P, Cockburn A, Newgrain K (2001) Parental investment in male and female offspring by the Peregrine Falcon, Falco peregrinus. Emu 101:95-103

Brown KM, Morris RD (1996) From tragedy to triumph: renesting in Ring-billed Gulls. Auk 113:23-31

Buczyński A (2000) Straty jaj w koloniach mewy pospolitej (Larus canus) na Wiśle-znaczenie trzeciego jaja w lęgu. MSc Thesis, Warsaw University, Warsaw

Bukacińska M (1999) Wpływ opieki rodzicielskiej na sukces reprodukcyjny u mewy pospolitej Larus canus. PhD Dissertation, Institute of Ecology, Dziekanów Leśny

Bukacińska M, Bukaciński D (1993) The effect of habitat structure and nest density on territory size and territorial behaviour in the black-headed gull (Larus ridibundus). Ethology 94:306-316

Bukaciński D (1998) Adaptacyjne znaczenie terytorializmu u mewy pospolitej Larus canus. PhD Dissertation, Institute of Ecology, Dziekanów Leśny

Bukaciński D (2015) Strategia czynnej ochrony zagrożonej awifauny wysp środkowej Wisły: podręcznik najlepszych praktyk. OTOP, Marki

Bukaciński D, Bukacińska M (1994) Czynniki wpływające na zmiany liczebności i rozmieszczenie mew, rybitw i sieweczek na Wiśle środkowej. Not Orn 35:79-97

Bukaciński D, Bukacińska M (1995) The factors limiting breeding success in the Black-headed Gull (Larus ridibundus) in different habitat types on the middle course of the Vistula River, Poland. Arch. fur Hydrobiol. 101. Large Rivers 9:221-228
Bukaciński D, Bukacińska M (1996) Uwarunkowania agresji u mew i rybitw w okresie lęgowym. Not Orn 37:97-111

Bukaciński D, Bukacińska M (2000) The impact of mass outbreaks of black flies (Simuliidae) on the parental behaviour and breeding output of colonial common gulls (Larus canus). Ann Zool Fennici 37:43-49

Bukaciński D, Bukacińska M (2003) Larus canus Common Gull. In: Parkin D (ed) Birds of Western Palearctic update 5. Oxford University Press, Oxford, pp 13-47

Bukaciński D, Bukacińska M (2008) Threatened bird species of the middle Vistula River islands: status, necessity for protection and proposed activities. In: Uchmański J (ed) Theoretical and applied aspects of modern ecology. UKSW, Warszawa, pp 219-239

Bukaciński D, Bukacińska M (2015a) Kluczowe gatunki ptaków siewkowych na środkowej Wiśle: biologia, ekologia, ochrona i występowanie. T.1. Mewa siwa Larus canus. Monografia. STOP, Warszawa

Bukaciński D, Bukacińska M (2015b) Kluczowe gatunki ptaków siewkowych na środkowej Wiśle: biologia, ekologia, ochrona i występowanie. T.2. Śmieszka Chroicocephalus ridibundus. Monografia. STOP, Warszawa

Bukaciński D, Bukacińska M, Lubjuhn T (2000) Adoption of chicks and the level of relatedness in common gull, Larus canus colonies: DNA fingerprinting analyses. Anim Behav 59:289-299

Bukaciński D, Keller M, Buczyński A, Bukacińska M (2017) Awifauna lęgowa koryta środkowej Wisły w roku 2009-zmiany liczebności i rozmieszczenia w ciągu ostatnich 36 lat. In: Keller M, Kot H, Dombrowski A, Rowiński P, Chmielewski S, Bukaciński D (eds) Ptaki środkowej Wisły. M-ŚTO, Pionki, pp 97-127

Bukaciński D, Bukacińska M, Buczyński A (2018) Threats and the active protection of birds in a riverbed: postulates for the strategy of the preservation of the middle Vistula River avifauna. Stud Ecol Bioethic 16(4):5-30

Bukaciński D, Bukacińska M, Buczyński A (2020) Offspring sex ratio in the first and replacement clutches of the mew gulls (Larus canus): breeding tactics in the riverine population of a sexually size-dimorphic bird. Waterbirds (in press)

Burnham KP, Anderson DR (2002) Model selection and multimodel inference: a practical information-theoretic approach, 2nd edn. Springer, New York

Butler RG, Janes-Butler S (1983) Sexual differences in the behaviour of adult Great Black-backed Gulls (Larus marinus) during the pre- and post-hatching periods. Auk 100:63-75

Carranza J (2004) Sex allocation within broods: the intrabroodsharing out hypothesis. Behav Ecol 15:223-232

Carranza J, Polo V (2012) Is there an expected relationship between parental expenditure and sex ratio of litters or broods? Anim Behav 84:67-76

Charnov E (1982) The theory of sex allocation. Princeton University Press, Princeton

Chmielewski S, Tabor J (2017) Charakterystyka przyrodnicza środkowej Wisły. In: Keller M, Kot H, Dombrowski A, Rowiński P, Chmielewski S, Bukaciński D (eds) Ptaki środkowej Wisły. M-ŚTO, Pionki, pp 17-29

Clutton-Brock TH (1991) The evolution of parental care. Princeton University Press, Princeton

Cockburn A, Double M (2008) Cooperatively breeding superb fairywrens show no facultative manipulation of offspring sex ratio despite plausible benefits. Behav Ecol Sociobiol 62:681-688

Cockburn A, Legge S, Double M (2002) Sex ratios in birds and mammals: can the hypotheses be disentangled. In: Hardy ICW (ed) Sex ratios: concepts and research methods. Cambridge University Press, Cambridge, UK, pp 266-286 
Cook MI, Monaghan P (2004) Sex differences in embryo development periods and effects on avian hatching patterns. Behav Ecol 15:205-209

Cramp S, Simmons KEL, Brooks D, Collar N, Dunn E, Gillmor R, Hollom P, Hudson R, Nicholson E, Ogilvie M (1985) Handbook of the birds of Europe, the Middle East and North Africa. The birds of Western Palearctic. Vol. III: waders to gulls. Oxford University Press, Oxford

Dejtrowski R (1993) Rozwój postembrionalny piskląt mewy pospolitej (Larus canus L. 1758) w zależności od kolejności klucia i siedliska. MSc Thesis, Warsaw University, Warsaw

Fjeldså J (1978) The Black-headed Gull. Biological monographs. AV-Media, Copenhagen

Fox J (2003) Effect displays in $\mathrm{R}$ for generalised linear models. J Stat Softw 8:1-27

Frank SA (1990) Sex allocation theory for birds and mammals. Annu Rev Ecol Syst 21:13-55

Fridolfsson AK, Ellegren H (1999) A simple and universal method for molecular sexing of non-ratite birds. J Avian Biol 30:116-121

Galipaud M, Gillingham MAF, Dechaume-Moncharmont F-X (2017) A farewell to the sum of Akaike weights: the benefits of alternative metrics for variable importance estimations in model selection. Methods Ecol Evol 8:42-49

Glutz von Blotzheim UN, Bauer KM (1982) Handbuch der Vögel Mitteleuropas. Band 8/II. Charadriiformes. Akademische Verlag, Wiesbaden

González-Solís J, Becker PH, Wendeln H, Wink M (2005) Hatching sex ratio and sex specific chick mortality in common terns Sterna hirundo. J Ornithol 146:235-243

Green M, Sambrook J (2012) Molecular cloning: a laboratory manual, 4th edn. Cold Spring Laboratory Press, Cold Spring Harbor

Griffiths R, Double MC, Orr K, Dawson RJG (1998) A DNA test to sex most birds. Mol Ecol 7:1071-1075

Grueber CE, Nakagawa S, Laws RJ, Jamieson IG (2011) Multimodel inference in ecology and evolution: challenges and solutions. $\mathrm{J}$ Evol Biol 24:699-711

Harrison XA, Donaldson LA, Correa-Cano ME, Evans J, Fisher DN, Goodwin CED, Robinson BS, Hodgson DJ, Inger R (2018) A brief introduction to mixed effects modelling and multi-model inference in ecology. PeerJ 6:e4794

Heaney V, Monaghan PA (1995) Within-clutch trade-off between egg production and rearing in birds. Proc R Soc Lond B 261:361-365

Hipfner JM, Gaston AJ, Martin DL, Jones IL (1999) Seasonal declines in replacement egg-laying in a long-lived, arctic seabird: costs of late breeding or variation in female quality? J Anim Ecol 68:988-998

Ilichev VD, Zubakin VA (eds) (1988) Pticy SSSR, vol 4. Nauka, Moskva

Kalmbach E, Griffiths R, Crane JE, Furness RW (2004) Effects of experimentally increased egg production on female body condition and laying dates in the great skua Stercorarius skua. J Avian Biol 35:501-514

Kalmbach E, Furness RW, Griffiths R (2005) Sex-biased environmental sensitivity: natural and experimental evidence from a bird species with larger females. Behav Ecol 16:442-449

Kharitonov SP (1975) K izucheniiu ekologii razmnozheniia i struktury kolonii obyknovennoi chaiki. In: Flint VE (ed) Kolonialniye gnezdovya okolovodnykh ptits i ikh okhrana. MOIP, Moskow, pp 105-106

Kim S-Y, Monaghan P (2006) Sex of the first hatched chick influences survival of the brood in the herring gull (Larus argentatus). $\mathrm{J}$ Zool 270:116-121

Komdeur J (2012) Sex allocation. In: Royle NJ, Smiseth PT, Kolliker $M$ (eds) The evolution of parental care. Oxford University Press, Cambridge, pp 171-188
Komdeur J, Pen I (2002) Adaptive sex allocation in birds: the complexities of linking theory and practice. Philos Trans R Soc B Biol Sci 357:373-380

Korzenecka P (2019) Ekologia rozrodu śmieszki Chroicocephalus ridibundus na wyspach środkowej Wisły w roku 2018. BSc Thesis, Cardinal Stefan Wyszyński University of Warsaw, Warsaw

Leech DI, Hartley IR, Stewart IRK, Griffith SC, Burke T (2001) No effect of parental quality or extrapair paternity on brood sex ratio in the blue tit (Parus caeruleus). Behav Ecol 12:674-680

Ležalova R, Tkadlec E, Obornik M, Šimek J, Honza M (2005) Should males come first? The relationship between offspring hatching order and sex in the black-headed gull Larus ridibundus. J Avian Biol 36:478-483

Lundberg C-A, Väisänen RA (1979) Selective correlation of egg size with chick mortality in the black-headed gull (Larus ridibundus). Condor 81:146-156

Maddox JD, Weatherhead PJ (2009) Seasonal sex allocation by common grackles? Revisiting a foundational study. Ecology 90:3190-3196

McDonald PG, Olsen PD, Cockburn A (2005) Sex allocation and nestling survival in a dimorphic raptor: does size matter? Behav Ecol 16:922-930

Merkling T, Leclaire S, Danchin E, Lhuillier E, Wagner RH, White J, Hatch SA, Blanchard P (2012) Food availability and offspring sex in a monogamous seabird: insights from an experimental approach. Behav Ecol 23:751-758

Merkling T, Welcker J, Hewison AJM, Hatch SA, Kitaysky AS, Speakman JR, Danchin E, Blanchard P (2015) Identifying the selective pressures underlying offspring sex-ratio adjustments: a case study in a wild seabird. Behav Ecol 26:916-925

Merkling T, Hatch SA, Leclaire S, Danchin E, Blanchard P (2019) Offspring sex-ratio and environmental conditions in a seabird with sex-specific rearing costs: a long-term experimental approach. Evol Ecol 33:417-433

Miller SA, Dykes DD, Polesky HF (1988) A simple salting out procedure for extracting DNA from human nucleated cells. Nucleic Acid Res 16(3):1215

Monaghan P, Nager RG, Houston DC (1998) The price of eggs: increased investment in egg production reduces the offspring rearing capacity of parents. Proc R Soc Lond B 265:1731-1735

Myers JH (1978) Sex ratio adjustment under food stress: maximization of quality or numbers of offspring? Am Nat 112:381-388

Nager RG, Monaghan P, Griffiths R, Houston DC, Dawson R (1999) Experimental demonstration that offspring sex ratio varies with maternal condition. Proc Natl Acad Sci USA 96:570-573

Nager RG, Monaghan P, Houston DC, Genovart M (2000a) Parental condition, brood sex ratio and differential young survival: and experimental study in gulls (Larus fuscus). Behav Ecol Sociobiol 48:452-457

Nager RG, Monaghan P, Griffiths R, Houston DC, Dawson R (2000b) Within-clutch trade-offs between the number and quality of eggs: experimental manipulations in gulls. Ecology 81:1339-1350

Nager RG, Monaghan P, Houston DC (2001) The cost of egg production: increased egg production reduces future fitness in gulls. $\mathrm{J}$ Avian Biol 32:159-166

Oddie KR, Reim C (2002) Egg sex ratio and paternal traits: using within-individual comparisons. Behav Ecol 13:503-510

Onno S (1967) Kalakajaka pesitsusökoloogiast. [Nesting ecology of the Common Gull]. Ornitoloogiline Kogumik 4:114-148

Ostrowska J (1995) Ekologia żerowania mew na Wiśle w okresie lęgowym, ze szczególnym uwzględnieniem mewy pospolitej (Larus canus). MSc Thesis, Warsaw University, Warsaw

Pérez C, Velando A, Domınguez J (2006) Parental food conditions affect sex-specific embryo mortality in the yellow-legged gull (Larus michahellis). J Ornithol 147:513-519 
Pike TW, Petrie M (2003) Potential mechanisms of avian sex manipulation. Biol Rev 78:553-574

Pikulska A (2017) Wpływ drapieżnictwa wybranych ssaków na wyspowe populacje mewy siwej i śmieszki na odcinku środkowej Wisły. MSc Thesis, Cardinal Stefan Wyszyński University of Warsaw, Warsaw

R Core Team (2017) R: a language and environment for statistical computing. R Foundation for Statistical Computing, Vienna

Rattiste K, Lilleleht V (1986) Some aspects of the demography of the Common Gull Larus canus in Estonia. Vår Fågelvärld Suppl 11:179-186

Rattiste K, Lilleleht V (1987) Population ecology of the Common Gull Larus canus in Estonia. Ornis Fenn 64:25-26

Richards SA (2008) Dealing with overdispersed count data in applied ecology. J Appl Ecol 45:218-227

Richards SA (2015) Likelihood and model selection. In: Fox GA, Negret-Yankelevich S, Sosa VJ (eds) Ecological statistics: contemporary theory and application. Oxford University Press, Oxford, pp 58-80

Richards SA, Whittingham MJ, Stephens PA (2011) Model selection and model averaging in behavioural ecology: the utility of the IT-AIC framework. Behav Ecol Sociobiol 65:77-89

Roonem TM, Robertson RJ (1997) The potential to lay replacement clutches by tree swallows. Condor 99:228-231

Rosivall B, Torok J, Hasselquist D, Bensch S (2004) Brood sex ratio adjustment in collared flycatchers (Ficedula albicollis): results differ between populations. Behav Ecol Sociobiol 56:346-351

Różycki AŁ (2014) Fenologia rozrodu i produkcja jaj mew: uwarunkowania i konsekwencje w warunkach środkowej Wisły. PhD Dissertation, University of Białystok, Białystok

Seutin G, White BN, Boag PT (1991) Preservation of avian blood and tissue samples for DNA analysis. Can J Zool 69:82-90

Southern LK (1981) Sex-related differences in territorial aggression by Ring-billed Gulls. Auk 98:117-129
Stearns S (1992) The evolution of life histories. Oxford University Press, Oxford

Storey AE (1987) Adaptation for marsh nesting in Common and Forster's terns. Can J Zool 65:1417-1420

Torres R, Drummond H (1999) Does large size make daughters of the blue-footed booby more expensive than sons? J Anim Ecol 68:1133-1141

Trivers RL, Willard DE (1973) Natural selection of parental ability to vary the sex ratio of offspring. Science 179:90-92

Uller T (2006) Sex-specific sibling interactions and offspring fitness in vertebrates: patterns and implications for maternal sex ratios. Biol Rev 81:207-217

Weimerskirch H, Lys P (2000) Seasonal changes in the provisioning behaviour and mass of male and female Wandering Albatrosses in relation to growth of their chicks. Polar Biol 23:733-744

Weimerskirch H, Barbaud C, Lys P (2000) Sex differences in parental investment and chick growth in wandering albatrosses: fitness consequences. Ecology 81:309-318

Wendeln H, Becker PH, González-Solís J (2000) Parental care of replacement clutches in common terns (Sterna hirundo). Behav Ecol Sociobiol 47:382-392

West SA (2009) Sex allocation. Princeton University Press, Princeton Wiśniewska M (2014) Wpływ wielkości i kondycji matek na inwestycje w lęg u mew na środkowej Wiśle. MSc Thesis, Cardinal Stefan Wyszyński University of Warsaw, Warsaw

Wooller RD (1980) Repeated laying by kittiwakes Rissa tridactyla. Ibis 122:226-229

Publisher's Note Springer Nature remains neutral with regard to jurisdictional claims in published maps and institutional affiliations.

\section{Affiliations}

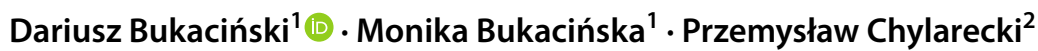

1 Institute of Biological Sciences, Cardinal Stefan Wyszyński University of Warsaw, Wóycickiego 1/3, 01-938 Warsaw, Poland
2 Museum and Institute of Zoology, Polish Academy of Sciences, Wilcza 64, 00-679 Warsaw, Poland 